\title{
Looking through the Vizão Feita por Xpo a el Rey Dom Affonso Henriques (1659) Franciscans in India and the legitimization of the Braganza monarchy
}

\author{
Ângela Barreto Xavier \\ Instituto de Ciências Sociais - Universidade de Lisboa. Av. Prof. Aníbal Bethencourt, 9. 1600-089. Lisbon, Portugal \\ e-mail:angela.xavier@ics.ulisboa.pt \\ ORCID iD: http://orcid.org/0000-0002-4367-6647
}

Submitted: 3 November 2015. Accepted: 25 April 2016

\begin{abstract}
Early modern Portuguese political providentialism has attracted significant scholarly interest in recent years. Whether in reference to the legitimization of imperialism in the fifteenth and sixteenth centuries, to the divine justification of royal power in the sixteenth and seventeenth centuries (especially after 1640), to Sebastianism, the Fifth Empire and other forms of millenarism, or to the uses of astrology, scholars have demonstrated that political providentialism was a familiar language to the Portuguese monarchy.

Little is known, however, about the formulation and spread of political providentialism in the Asian part of the Portuguese Empire. In this paper I provide a more complex picture of the dissemination of this language in the Estado da Índia through an analysis of the treatise Vizão de Affonso Henriques, written in Goa by Friar António de S. Thiago, in the year 1659. How does this treatise relate to metropolitan political providentialism, namely in the context of the legitimization of the Braganza monarchy? How is Franciscanism crucial in the treatise's structure? And can the treatise be located at the crossroads of Euro-Asiatic political culture?
\end{abstract}

KEYWORDS: Political Providentialism; Franciscans; Portuguese Empire; India.

Citation / Cómo citar este artículo: Barreto Xavier, Ângela (2016) "Looking through the Vizão Feita por Xpo a el Rey Dom Affonso Henriques (1659). Franciscans in India and the legitimization of the Braganza monarchy". Culture \& History Digital Journal, 5 (2): e012. doi: http://dx.doi.org/10.3989/chdj.2016.012.

RESUMEN: Mirar a través de la Vizão Feita por Xpo a el Rey Dom Affonso Henriques (1659). Franciscanos en la India y la legitimación de la monarquía Braganza.- En los últimos años el estudio del providencialismo político en el Portugal Moderno ha despertado un significativo interés académico. Ya sea como referencia a la legitimación del imperialismo de los siglos XV y XVI, ya a la justificación divina del poder real en los siglos XVI y XVII (sobre todo después de 1640), como al Sebastianismo, al Quinto Imperio y demás formas de milenarismo o a los usos de la astrología, los especialistas han demostrado que el providencialismo era una lenguaje conocido en la monarquía portuguesa.

Poco se sabe, sin embargo, de su formulación y propagación en la parte asiática del Imperio portugués. En este trabajo se propone una imagen más compleja de la difusión del providencialismo político en el Estado de la India a través de un análisis del tratado, Vizão de Affonso Henriques, escrito en Goa por Fray Antonio de S. Thiago en el año 1659. ¿Cómo se relaciona este tratado con el providencialismo político metropolitano, esto es, con el contexto de la legitimación de la monarquía Braganza? ¿Jugó el franciscanismo un papel crucial en la estructura del tratado? ¿Puede localizarse este tratado como un cruce de la cultura política euro-asiática?

PALABRAS CLAVE: Providencialismo político; Franciscanos; Imperio Portugués; India.

Copyright: (C) 2016 CSIC. This is an open-access article distributed under the terms of the Creative Commons Attribution License (CC BY) Spain 3.0. 


\section{INTRODUCTION}

Early modern Portuguese political providentialism has attracted significant scholarly interest in recent years. Whether in reference to the legitimization of imperialism in the fifteenth and sixteenth centuries, to the divine justification of royal power in the sixteenth and seventeenth centuries (especially after 1640), to Sebastianism, the Fifth Empire and other forms of millenarism, or to the uses of astrology, scholars have demonstrated that political providentialism was not only a familiar language to the Portuguese monarchy, but also an important component in the making of early modern Portuguese identity (Torgal, 1982; Buescu, 1987; Marques, 1988; Lima, 2010; Valdez, 2010). Early modern Portugal was in many ways similar, therefore, to other early modern political entities, not only to European ones such as Spain and England but also to entities further afield, such as the Ottoman, Safavid and Mughal Empires (see among others Phelan, 1970; Lerner, 1983; Kagan, 1990; Finlay, 1998; GarcíaArenal, 2000; Babayan, 2002; Alam, 2004; Fleischer, 2007; Brady and Buttersworth, 2010; Bang and KoŁodziesjczyk, 2012; Moin, 2012; Alam and Subrahmanyam, 2013; Lefèvre, forthcoming).

One of the characteristics of Portuguese political providentialism was its presence in the metropolitan world, as well as in imperial territories, namely Brazil (see among others Melo, 1997; Cohen, 1998; Kantor, 2007; Lima, 2010; Valdez, 2010). Nevertheless, less is known about its formulation and diffusion in other parts of the Portuguese Empire, namely Asia. It is true that $O s$ Lusiadas, structurally based on providentialist beliefs, had been written when Camões was travelling through the Indian Ocean. However, besides a limited number of studies on the letters of Afonso de Albuquerque by scholars such as Francisco Bethencourt, and the essays of Sanjay Subrahmanyam, George Winius, Ines Županov and Zoltán Biedermann on providentialism and millenarism in the sixteenth and seventeenth centuries (Bethencourt, 2007; Subrahmanyam, 2001; Winius, 2001; Županov, 2007; Biedermann, 2012; Xavier, 2014a), we still know very little about the relevance of this language in the political culture of those who lived in the Estado da Índia. In fact, providentialist topics were common not only in the writings of major figures like Camões, Albuquerque and Queiroz, but also in letters sent by anonymous officials to the Portuguese court, and vice-versa, as well as in regular conversations.

A study of the manuscript treatise Vizão feita por Хро a el rey Dom Affonso Henriques no Campo de Ourique, written in Goa in 1659 by the Franciscan friar Antonio de S. Thiago, ${ }^{1}$ complements the insights provided by Županov and Biedermann into the circulation and mobility of providentialist languages in seventeenth-century Estado da Índia. Namely, it reinforces the idea that in order to understand the imagination of the future in post-Restoration Portugal, one must consider the multiple voices coming from across the world which were instrumental in imagining that future (Biedermann, 2012).
With 119 well-preserved folios, several hand-made images and numbers, and letters of cabalistic nature, the most striking thing offered by a quick reading of this (not always discursively coherent) treatise is a reminder of how relevant Franciscan providentialism was to the making of Portuguese providentialism in a historiographical scene dominated by Jesuit authors like António Vieira (Županov and Biedermann's work are both about Jesuits). Although it has been studied in more depth thanks to the unquestionable primacy of António Vieira's treatises (Vieira, 1718, 2000, 2007), Jesuit providentialism does not exhaust the richness of Portuguese providentialist languages. On the contrary, the relations between the writings of Jesuits and Franciscans should also be analyzed; S. Thiago's treatise, for example, must be located in relation to the later writings of Fernão de Queiroz. Beyond the probable connections between these writings, historiography has already shown that in the fifteenth and sixteenth centuries prophetism, visions, and providentialism had a clear Franciscan trace, following the path laid out in previous centuries (Carvalho, 1991, 1994; Rosa, 2010). The same was true in other European principalities (Aurell, 1997).

Furthermore, the crucial presence of Franciscans in the Portuguese royal court during the medieval and early modern periods, as well as their massive territorial inscription between the sixteenth and eighteenth centuries (on this, see Rosa, 2010 and Marques, 1988, 2nd volume, annexes) are indicators of their early modern relevance, if not hegemony. However, historians have not paid sufficient attention to the structural consequences of this overwhelming presence in the shaping of early modern experiences in the Portuguese-speaking world. The dominance of Franciscans in early modern Portugal is especially important when considering the Restoration period, when the Braganza dynasty — which had intensively supported the Franciscan orders and received their support in turn (Carvalho, 1999) - claimed the Portuguese crown. Unsurprisingly, if almost completely neglected by historians, one of the Franciscan strategies during this period was to be fully involved in the production of legitimist discourses, either through sermons, such as those studied by João Francisco Marques (Marques, 1988), or through other types of writings, like S. Thiago's treatise.

The intimacy between Franciscans and Portuguese elites had its corresponding imperial expression in the Estado da Índia. Here, Franciscans and colonial elites of Portuguese origin frequently had common interests. As I have argued elsewhere, Franciscan writing in these territories can also be considered an expression of "creole" writing and thinking (Xavier, 1997; Sousa, 2013). ${ }^{2}$ Furthermore, Habsburg domination had been harsh for the religious orders established in India, under strict control of the crown and the viceroyalty (Ferreira, 2011: 17, 8182). A change in dynasty could represent a change in this policy, too. This means that the mid-seventeenth-century Estado da Índia was a perfect environment for the interests of local elites of Portuguese origins, Franciscans, and the Braganza monarchy to converge. As José Miguel 
Moura Ferreira has reminded us, the Franciscan archbishop of Goa, Francisco dos Mártires, also had an important role in the recognition of John IV as the legitimate king of Portugal in 1641. Was Vizão feita por Xpo a el rey Dom Affonso Henriques an expression of the explicit acceptance of the Braganza dynasty by the elites of Goa, as well as by the Franciscans, one of the religious orders which had been harshly "domesticized" under the Habsburgs?

These problems deserve further attention, but there are also further grounds to justify the critical position of this treatise as an historical source. In fact, if the seventeenth century was an important period for the diffusion of Portuguese political providentialism, the same thing was going on in Indian polities, and Vizão appears to have a kind of sensitivity to these Indian languages. Was this treatise a cultural object located at the crossroads of EuroAsiatic providentialist political imagination, a material testimony of its hybridity?

In this paper I make three arguments intended to offer some provisional answers to the questions listed above. Firstly, I argue that Friar Antonio de S. Thiago's treatise is fully engaged with Portuguese intellectual and political dynamics, contributing to a more complex understanding of the formulation, dissemination and circulation of providentialist ideas within the Portuguese-speaking world. The treatise, of course, does not exist in a vacuum, so it follows that serious investigation of expressions of Portuguese providentialism in the Estado da Índia is necessary to understand the history of Portuguese providentialism as a whole. Secondly, following the work of José Adriano de Carvalho (Carvalho, 1991, 1994) and of Maria de Lurdes Rosa (Rosa, 2010), I contend that studying Franciscan providentialism is also crucial to understanding providentialist languages within the Portuguese world. The Franciscans were deeply enmeshed in the Portuguese religious (and therefore cultural) order. Consequently, historical analysis of Franciscan contributions to larger historical processes are essential to have a less biased (namely, less Jesuitic) understanding of these processes. Thirdly, I consider that, for several reasons, this treatise was a hybrid object, a material testimony to the vibrant cultural life of seventeenth-century Goa, a place at the crossroads of Euro-Asiatic political culture.

The first section of this paper compresses the discussion of the first two arguments. The second, shorter, section looks in greater detail at the third.-

Certain aspects and themes of undoubted relevance will not be discussed here. One is the Franciscan-Jesuit relationship in providentialist traditions and the place providentialism played in the more general FranciscanJesuit rivalry in the early modern period, particularly in the Braganza court. While an unquestionably relevant topic, and also because Father António Vieira's Esperanças de Portugal, one of the most important works of Portuguese millenarism, also dates from 1659, this discussion is not addressed here besides a few comments. Another absent discussion, linked with the previous one, is related to the circulation and reception of the treatise. I have hitherto been unable to find any information about this decisive aspect in order to understand the impact or lack thereof- of this unique manuscript. I am quite conscious of Fernando Bouza's inspiring pages about the intricacies of the relationship between manuscript and printed objects and their dissemination (see especially Bouza, 2001), but do not explore this aspect intensively in this paper. Neither is the cabalistic and esoteric nature of this treatise (full of numbers and decomposed syllables which suggest, each of them, secret meanings), referring to a widespread tradition in the early modern Iberian world which frequently points towards New Christian cultural roots, discussed here. This is a vast field of research, which, due to its breadth and complexity, must be, for now at least, neglected. Finally, the visual narrative which expands the written narrative is not investigated with the attention it deserves.

In short, this essay is a modest introduction to the multiple worlds of interpretation this treatise inspires rather than a deep study of its several avenues of research.

\section{VIZÃO FEITA POR XPO A EL REY DOM AFFONSO HENRIQUES AND THE SEVENTEENTH-CENTURY PORTUGUESE POLITICAL PROVIDENTIALISM}

As noted above, providentialism (the belief in God's intervention in human affairs, helping to explain perplexing or threatening events) was part of mainstream early modern Portuguese culture. The origins of this providentialism have been widely debated; among other explanations, Claude Stuczinski drew attention to some of the Hebrew roots of its Iberian expression, which explain (among other features) why the idea that the Iberians were "divinely elected" could spread so easily, that they were the true successors of the Jews, and that the expansion of Christianity could therefore benefit almost the whole world. This would contribute to, as Stuczinski has put it, "the emergence of Iberian messianic-providential ideologies prevalent during the period of the overseas discoveries and the early stages of American colonization" (Stuczinski, 2008). The "millennial kingdom" of the Franciscans in the New World, to use John Leddy Phelan's term, and the "millenarism" of King Emmanuel were just two of many expressions of these ideologies (Phelan, 1970; Thomaz, 1990; Subrahmanyam, 2001). In both, there was a constant tension between election and rejection, inclusiveness and exclusiveness, especially evident in anti-converso providentialist writings, where "Old Christians" were presented as superior to "New" ones (Stuczinski, 2008: 382).

In the case of Portugal, the topos of the "divine election" was strongly reactivated during and after the events of 1640, complementing the providentialist legitimization of Portuguese "discoveries" during the fifteenth and sixteenth centuries. This can be seen in treatises such as the following: Francisco Lopes' Favores do ceo: do braço do Christo que se despregou da cruz, \& de outras marauilhas dignas de notar (Lisbon: António Álvares, 1642); António Carvalho de Parada's Justificaçam dos portugueses sobre a 
acçam de libertarem seu Reyno da obediencia de Castella (Lisbon: António Craesbeeck, 1641); Gabriel de Almeida's Restauração de Portugal Prodigiosa of (Lisbon: António Álvares, 1641); the Franciscan Francisco de Santo Agostinho de Macedo's Philippica Portuguesa (Lisbon: António Álvares, 1645); and António Vieira's “Sermão dos Bons Anos" (Lisbon: Lourenço de Anvers, 1642). It can also be seen in many sermons as identified by João Francisco Marques. In this new "City of God", the Portuguese, among all Iberians, would be the ones to bring universal peace to the rest of the world (Torgal, 1982, I: $241 \mathrm{ff}$.; Marques, 1988, 2007).

The idea of the Portuguese as the "elected people", combined with that of their political destiny as guides of the world, is clearly present in Vizão feita por Xpo a el rey Dom Affonso Henriques. It is fair to say that the first part of the treatise is dedicated to establishing the translatio which transfers the mission attributed to Israel and the Jewish people to Portugal and the Portuguese (Vizão: fls. 7-13) in the figure of Afonso Henriques, the anointed one (Vizão: fls. 7-20). Several analogies, following the usual protocol of this type of writing, are drawn in this first part, namely between Afonso Henriques and Abraham, Moses, King David, Gideon (whom Afonso Henriques was supposedly reading about at the time of his vision), Daniel, Saint Peter and the angel of the Apocalypse (Vizão: fls. 20-47; Buescu, 1987; Lima, 2010). Taken from Portuguese history and both the Old and the New Testaments, these analogies helped to sustain the idea that this translatio from the Jewish people to the Portuguese had been Christ's decision, from the past (Afonso Henriques) to the present and to the future (the Braganza dynasty) (Vizão: fl. 8, fl. 129).

After establishing that Afonso Henriques was the anointed one and the Portuguese the new elected people, there was a clear move, in Vizão and in Braganza-legitimizing literature more generally, from the historical past towards the lived present. Like the Jews, who had been punished for their sins and lost their status as an "elected people", the death of King Sebastian in 1578 and the crisis of 1580 were also understood as a punishment for Portuguese sins. For friar S. Thiago, furthermore, Habsburg rule was equivalent to Babylonian captivity (Vizão: fls 62 ff), and the Restoration was liberation from it. In order to cope with these challenges, the second logical step was to establish - as many other treatises of this type also didthat John IV, and not the Spanish kings (as Philip III of Spain tried to argue ${ }^{4}$ ) was the legitimate heir to the sacred kingship established by Christ in Afonso Henriques and his generation. The second part of S. Thiago's treatise materializes this intention, which can only happen by establishing the connection between what had happened to Afonso Henriques —namely the "Miracle of Ourique" and what was happening to John IV and his successors.

The dissemination and reception of the "Miracle of Ourique" was an important moment of the making of the discursive pillars of Portuguese identity. This miracle concerned the apparition of Christ crucified to Afonso Henriques, at that time a nobleman, just before the Battle of Ourique, after an old man had told him in a dream of the glories reserved for him. The (Christian) Portuguese defeated the (Muslim) Moors on $25^{\text {th }}$ July 1139 , and on the following day Afonso Henriques became the first king of Portugal. Victorious against "Spain" and the "Moors", Afonso Henriques stood for the autonomy of the Portuguese kingdom in the Iberian world, as well as for the fight against the infidels and for the expansion of Christianity (later extra territorium).

Analyzed by several historians since Alexandre Herculano, the legend of Ourique inspired the political imagination of the House of Aviz, two decades after the Battle of Aljubarrota against Spain (1385) and four years after the conquest of Ceuta (1415), the event that initiated the Portuguese expansion extra territorium.-This myth was revived after attempts were made from the second half of the fifteenth century to sanctify the King at the Monastery of Santa Cruz de Coimbra; after Vasco da Gama's journey to India in 1498; and in the context of the "messianic atmosphere" of the court of King Emmanuel I, through the Chronica de D. Afonso Henriques, written in 1505 by Duarte Galvão, whose brother was the head of the aforementioned monastery (Lisbon: Off. Ferreyriana, 1726). The attempts to canonize Afonso Henriques during the governments of Emmanuel I and John III (Rosa, 2010), and his heroic representation in Os Lusíadas also played a part in this revival. ${ }^{5}$

The Iberian Union (1580-1640) stimulated its revival, providing the unsettled Portuguese with a sense of "national pride" and "distinctiveness". In his Restauração de Portugal Prodigiosa, Gregório de Almeida stated that the links between the realm of God and the kingdom of Portugal had already been prophesied by Ezra in the Old Testament, and that these connections had become explicit when the divinely-electd Afonso Henriques founded the (also divinely-elected) Portuguese monarchy (Almeida, 1643: 27, 237, 279). The separation from Spain and the fight against paganism intra and extra territorium, by Afonso Henriques and John IV alike, was presented as part of the earthly materialization of God's plan, and the new attempts to canonize the first Portuguese king were part of this process of mutual sacralization. The asymmetry between Portuguese military forces and their enemies in various battles (such as the Battle of São Mamede, the Battle of Aljubarrota and the Restoration battles which the Portuguese had already won) was presented as a proof of the divine choice. In short: if Afonso Henriques had been anointed to initiate Portuguese kingship, John IV and his successors were expected to rematerialize it (Torgal, 1982; Marques, 1988, 2007; Costa and Cunha, 2008; Lima, 2010).

All these ideas are present too in S. Thiago's treatise (Vizão: fls. 15, 29, 30v, 116, 134, 136, 141, 159). Complementing the description of the miracle and the controversies it had generated, in the third folio a "Goan" image of the miracle of Ourique is reproduced, stressing the idea that the mandate given to the king of Portugal was to turn his kingdom into a missionary one in order to convert the whole world (Vizão: fls.3-6). Prophecies from the Old Testament declared that the Portuguese were the second apostles and missionaries, and that they had been chosen 
by God to carry out the mission of universal conversion. In particular, they had been chosen to convert the East, because it was from the East that Christ had come. This destiny would be fulfilled under the Braganza dynasty, especially after many of its previously-lost overseas territories were restored to the Portuguese monarchy (Vizão: fl. 15,26 , fl. 110v).

Like many others, $\mathrm{S}$. Thiago remembered that a "miracle of the Cross" had also happened to John IV during his acclamation. At the Battle of Ourique, Christ had proclaimed: "I am founder and destroyer, and I found and destroy empires and kingdoms at will. I want, through you and your descendants, to create and to establish for myself an empire". At the time of King John's acclamation, Christ pulled his right hand away from the crucifix, thus restoring Afonso Henriques' kingship to his legitimate successor (Vizão: fls. 115-143v). In the following image (Fig. 1), the shield of Afonso Henriques already predicts this second miracle of the cross, showing the right hand of Christ moving. Depicted, as usual, with the weapons of the warrior, and called "Saint" as the legend went, Afonso Henriques was now attributed with prophetic faculties.

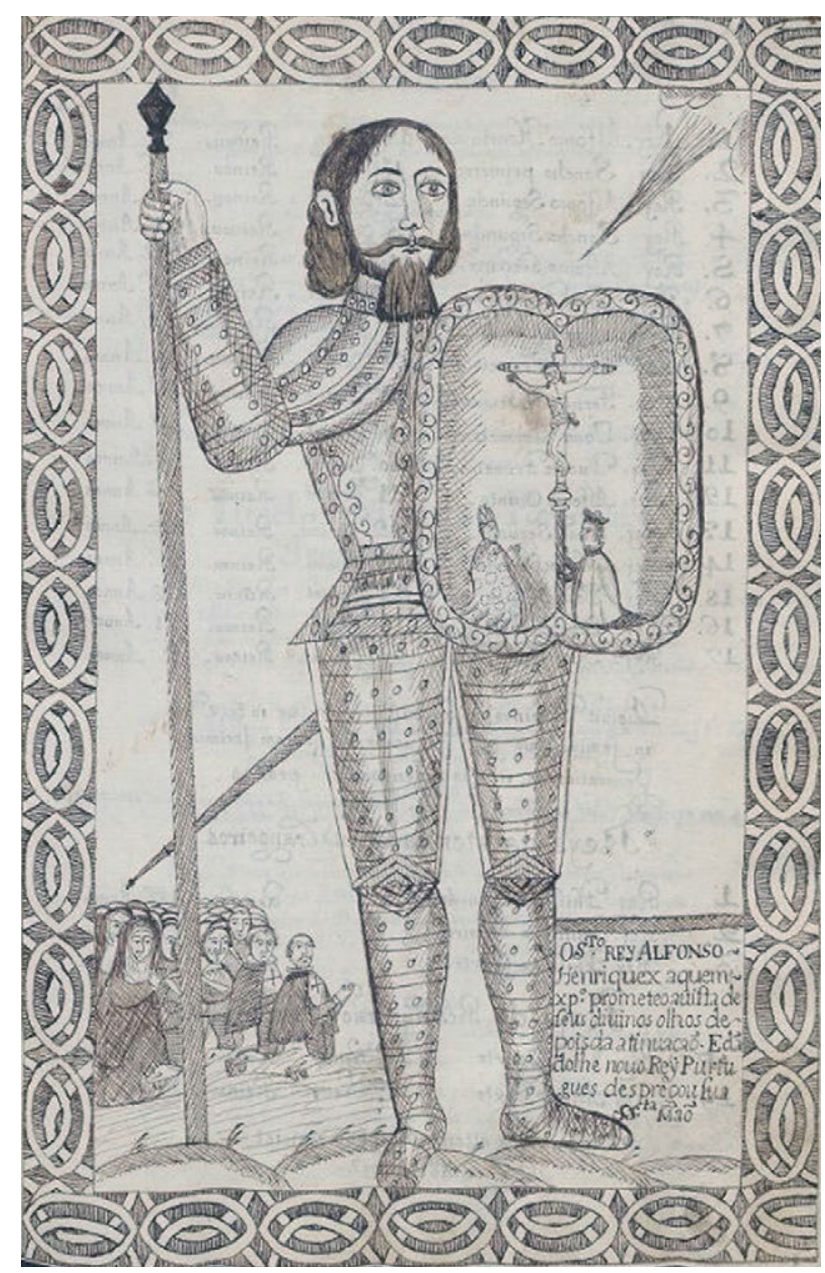

FIgURE 1. Afonso Henriques, Vizão..., Harvard University, Houghton Library, Ms Port 4666, fl. 12.
Vizão lists not only the Miracle of Lisbon, but also a series of similar miracles before, during and after the acclamation of John IV, in a rhetorical effort which aims to reinforce the legitimacy of the Braganza dynasty. Among these miracles, three had happened in no other place than Goa itself, in 1619, 1636 and 1641. Comets, astrological predictions and other celestial signs, and various narratives of Christ moving his eyes and hands while crucified were all signs of God's protection in the face of the political changes of the $1640 \mathrm{~s}$. S. Thiago does not refer, however, to the many visions which the Jesuit Pedro de Basto had in more or less the same period (Biedermann, 2012), either because they did not circulate among Franciscans, or because he had a clear intention of silencing Jesuit voices (he does not refer to Vieira either, perhaps because Vieira's most important millenarist works start precisely in 1659, with Esperanças de Portugal).

In 1619, Christ had appeared with his eyes set on Philip III of Spain (Philip II of Portugal) while he was attempting to "destroy", as S. Thiago put it, the Kingdom of Portugal through political means. A few years later, on $8^{\text {th }}$ February 1636, Christ opened his eyes again at the Convent of Santa Monica, twenty-six times - looking once more to the West, but also observing each nun with a benevolent look. This was the year when, in Madrid, the King and the council of Portugal were discussing whether to abandon India, according to S. Thiago, and this miracle of the cross was a sign of Christ's disagreement with Spain's decision. For eight days, Christ appeared to the nuns of Santa Monica, opening his eyes, speaking a few words and bleeding. Another miracle recorded by S. Thiago, whose meaning is not explained, took place five years later, in 1641, when, in the Church of the Holy Spirit in the village of Naroa, the nails pinning Chris to the cross were seen to fall down, as did the very image of Christ (Vizão: fl. 52, fl. 54v, fl 75; Teles, 2011).

It is clear that one of Antonio de S. Thiago's aims was to integrate the history of the Empire into the new dynasty's plans (Vizão: fls. 75-88). It is not surprising, therefore, that he openly claimed that the political and military support given by the Portuguese living in India, as well as by Indian converts, was essential to keeping those territories under the political dominion of the Portuguese monarchy, and was thereby of crucial importance to the materialization of God's plan (Vizão: fls. $11 \mathrm{v}-12,52-55$, 110-113, 122).

Providentialist literature supporting the Braganza dynasty (what Marques, 1988, called Brigantism) involved, however, the silencing of the strongest providentialist language of the first half of the seventeenth century - Sebastianism. ${ }^{6}$ The "second coming" of D. Sebastião had to be substituted by the idea that prodigious things were reserved, instead, to John IV and his descendants. In 1624, Manuel Bocarro Francês, in his Anacephaleoses da Monarchia Luzitana, had been the first to associate the "Encoberto" with the Braganzas (Lisbon: António Álvares, 1624). In 1642, Fr António Vieira, one of the iconic voices for this other translatio, had transformed the Sebastianist belief into a "Joanist" one in his "Sermão dos Bons 
Anos". The true king, he said, was not Sebastian, but, rather John IV (or one of his sons). These ideas were systematized in his later treatises (Vieira, 1718, 2000, 2007; Jordán, 2003; Lima, 2010; Valdez, 2010).

Although quoting only Bocarro Francês, and not Vieira, the same idea also structures Vizão feita por Xpo a el rey Dom Affonso Henriques. The birth of John IV's second son in the summer of 1643, named Afonso Henriques, was a marker of that continuity. Afonso VI, like Afonso Henriques, was physically disabled, which some considered as a sign of divine election as they had done with the medieval king (Rosa, 2010: 171). His birth was therefore presented as the accomplishment of earlier predictions (Xavier and Cardim, 2006) and Afonso VI became, for a while, the "desired king" and the recipient of "the hopes of Portugal" (Vizão: fls. fl. 15, 90-92v, 95-98, $141,146-149,158,168-169,138-141,192,144-172) .^{7}$

In fact, it was certainly not fortuitous - as I was reminded by Pedro Cardim - that this treatise is dated 1659 , since that was the year when Prince Afonso turned 16 and in which he should have acceded to the throne. Writing from distant Goa, the author took for granted that he was praising the new king; in reality back in Portugal, as is well-known, Queen D. Luisa de Gusmão and her supporters considered the young prince unable to take over the government. The queen remained in power until 1662, when Afonso VI took over the throne in the coup of Alcântara, led by the Count of Castelo Melhor, members of the nobility and António de Sousa de Macedo, one of the most important "Brigantists". This last figure was also the author of Lusitania Liberata Lusitania liberata ab injusto Castellanorum domínio: restituta legitimo Principi Serenissimo Joanni IV (London: Off. Richardi Heron, 1645), a book quoted by António de S. Thiago (Xavier and Cardim, 2006).

In order to sustain his arguments, S. Thiago also quoted minor local figures such as Gaspar Sinel, Amaro Moreira and a certain "conego Moreira". ${ }^{8}$ S. Thiago certainly had a connection with Gaspar Sinel, who worked for the Revenue Office of Goa, Ceylon and Mascate and who was a known captain circulating between the Indian and the Atlantic Oceans; but also with "conego Moreira" of the See of Goa, who, S. Thiago said, had contributed to the Sinel's book of prophecies. It is clear from the several references to Sebastianism, and the space reserved for arguing against it in Vizão feita por Xpo a el rey Dom Affonso Henriques (Vizão: fls. 89-98), that the belief was widely disseminated in the Estado da India. The treatise recounts the case of a false king claiming to be Sebastian appearing in Goa, and also gives us the name of several Goan Sebastianists: not only Amaro Moreira Campelo and "all Moreiras" ("conego Moreira" probably included), but also António Curvelos de Andrade, Álvaro Sebastião do Rosário, and Manuel Fernandes Aranha (Vizão: fls. 96v-97v).

There is no doubt that Vizão feita por Xpo a el rey Dom Affonso Henriques was fully integrated in the political providentialist dynamics of this period (albeit not fully reproducing the topoi present in the majority of this literature), and that these dynamics had an important sociologi- cal expression in the Estado da Índia. The encyclopedia of references found in the treatise confirms its participation in the wider genre of the Braganzas' providentialist-legitimist literature. Like any other treatise of this kind from this period, biblical references (especially from the Old Testament) were combined with references to "historical sources" (mainly the oath of Afonso Henriques) and different types of historical literature. Respectively, these three types account for 428 references ( $44.9 \%$ of the total), 129 references (13.5\%) and 397 references (41.6\%).

More than two thirds of the biblical references are taken from the Old Testament, and less than one third from the New Testament. Among these, Daniel and Isaiah - two of the most important points of reference in prophetic literature - and the Psalms are the most-commonly cited. Unsurprisingly, it is the Gospel of Saint John and the same author's Book of the Apocalypse which are most quoted from the New Testament. ${ }^{9}$

The remaining literary references $(41.6 \%$ of the total) can be divided into four types: the prophetic books written until 1640, where the heroic life and/or saintliness of Afonso Henriques was defended; books explicitly written or used to legitimize the rule of the Braganzas; books related to the history of the Portuguese Empire; and Franciscan books. The first category includes authors such as Fernão Lopes, Afonso de Cartagena, Duarte Galvão, Duarte Nunes de Leão, Camões, Pedro Mariz, Jorge Cardoso, Bernardo de Brito, António Brandão, Manuel de Faria e Sousa, António de Sousa de Macedo, Mateus Alemão, Manuel Bocarro Francês and André Avelar, and also Pedro Annes de Avellos, the author of Jardim Ameno, a prophetic treatise dedicated to D. Sebastião, which appeared in 1636 and in India in 1650 (Biedermann, 2012, 145: 172). The group does not, as mentioned above, include Fr. Antonio Vieira. The second category includes the most important writers of the Restoration period: Francisco Velasco Gouveia, João Salgado de Araújo, António de Sousa de Macedo (once again), Pedro de Sousa Pereira, D. Rodrigo da Cunha, António Pais Viegas, António Veloso de Lyra, João Baptista Morelli, M.A. Monteiro de Campos, Manuel das Chagas, Manuel Calado Salvador. The third category, despite containing the fewest books, introduces specifically "local" contexts, and includes authors such as João de Barros, Damião de Góis, Francisco de Gonzaga, António de Serpa and Manuel Barradas, but also "Indian writers" including Paulo da Trindade, Gaspar Sinel and Sebastião Giraldo.

Drawing from the first three categories, it is clear that S. Thiago relied most on Gregorio de Almeida's Restauração de Portugal Prodigiosa, one of the most common references in the context of legitimist literature of the Braganzas, D. Rodrigo da Cunha's Historia do Arcebispado de Lisboa, and Pedro Mariz's Dialogos de Varia Historia. Another book must also be mentioned, because of its parallels with S. Thiago's "Goan" treatise: O Valoroso Lucideno, e triumfo da Liberdade na Restauração de Pernambuco, written by Manuel Calado do Salvador, a member of the the Order of Saint Paul who had been born in Vila Viçosa and lived under the protection of the Braganza 
family. The book was published in Lisbon in 1648, and was put on the Index by 1655 , but was apparently still circulating in Goa. Naturally, S. Thiago used it to describe the Brazilian situation during the Restoration period -a period of conflict with the Dutch - instead of the proHabsburg Memorias diarias da Guerra do Brasil (1654), written by Duarte Albuquerque Coelho, a Portuguese noble who had stayed in Madrid. Lucideno also served as a source of more general arguments in favor of Goa.

The density of Franciscan references is comparatively lower - less than $10 \%$ of the total - although the first general chronicle of the Franciscan order, Marcos de Lisboa's Chronica dos Frades Menores, is referred to several times. The relative lack of references does not mean, however, that S. Thiago was not engaged in a Franciscan form of providentialism, but only that his book was intended to be read by a larger audience than a mere Franciscan one. In fact, this treatise is deeply inscribed in the long Franciscan providentialist and prophetic tradition; it was also the tradition most sensitive to millenarism. Franciscans, and namely the Observant Franciscans (and S. Thiago belonged to its Reformed branch) represented themselves as the anchors of the aspiration to a renovatio that this tradition entailed. This "Franciscanism" served to reinforce the position of these friars both close to the Braganza family and in the power structures in Goa.

The parallel established between Saint Francis receiving the stigmata, which occurred in 1224, 85 years after the Battle of Ourique, and the Miracle of Ourique, was clearly intentional on the part of S. Thiago. The title Vizão feita por Xpo a el rey Dom Affonso Henriques, in a Franciscan environment, was reminiscent of Saint Francis' vision. As Pamela Askew noted as far back as 1969, Saint Francis' visionary experiences became ever more important in post-Tridentine Franciscan imagery (Askew, 1969), which probably stimulated this type of comparison.

Indeed, as will be shown in the second part of this essay, a comparison of the pictorial structure of Giotto's Saint Francis Receiving the Stigmata (itself a reconstruction inspired by Saint Bonaventura's version of Francis' life) (Frugoni, 1993) and depictions of the Battle of Ourique (in frescoes, paintings and engravings), reveal striking parallels. This is especially relevant if we consider that one of the most important topoi of Franciscan literature, and one which was disseminated in Europe through the Chronica dos Frades Menores (Carvalho, 1994: 70ff; 2001: 57-58), was the assumption of the existence of a direct link between God and the Franciscans. This argument, as Silvério Lima reminded me, should be understood in relation to the rivalry with other religious orders that were already recognized in that position (such as the friars of Santa Cruz of Coimbra and of Alcobaça, for example This topos also structured the Franciscan treatises written in Goa by other figures: Friar Paulo da Trindade's Conquista Espiritual do Oriente from 1636 (Lisbon: Centro de Estudos Históricos Ultramarinos, 1962-1967), Friar Miguel da Purificação's Vida Evangélica dos frailes menores (Barcelona: Gabriel Noguez, 1641) and Friar Jacinto de Deos' Caminho dos frades menores (Lisbon:
Miguel Desldandes, 1689). In Vida Evangélica, the topos is not only the main argument of the text, but is also illustrated by several engravings, which were accompanied by mottos explaining their exact intention ("the intention of this engraving is...”). Purificação's goal was to demonstrate, repeatedly, that Saint Francis was the double of Christ, and the Franciscans Christ's contemporary imitators (Purificação, 1641).

The same topos is also structural to Antonio de S. Thiago's Vizão feita por Xpo a el rey Dom Affonso Henriques, which openly "nationalizes" it. Already by the second folio - that is, even before the depiction of Ourique- S. Thiago refers to the parallel between the wounds of Christ, the wounds of Saint Francis, and the five wounds in the arms of Portugal, an idea which is repeated later when he insists that one of Zechariah's prophecies, in the Old Testament, already drew a relation between the wounds of Christ, the stigmata of Saint Francis and the wounds in the arms of Portugal. This can be seen in the following original visual composition (Fig. 2).

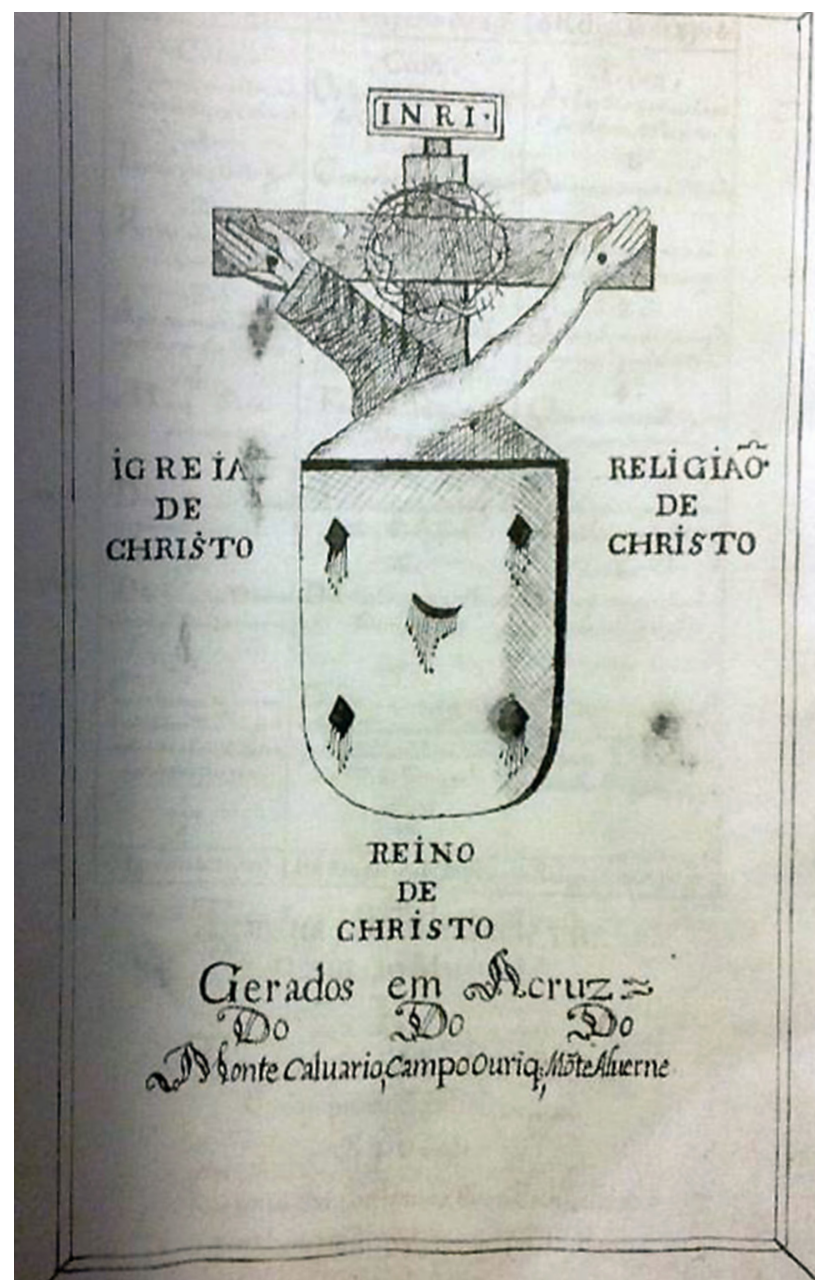

Figure 2. Parallels between Christ, Saint Francis, Afonso Henriques, Heaven, the Church of Christ (the Franciscans) and the kingdom of Christ (Portugal), in Vizão..., Harvard University, Houghton Library, Ms Port 4666, fl. 49v 
S. Thiago's ultimate intention was to establish parallels between Christ and King John IV, mediated by the parallels between Saint Francis (alter Christus) and Afonso Henriques. One aspect of the mythification of Afonso Henriques drew directly on the association between the wounds he received at the Battle of Ourique, where he defeated five Muslim kings, and the coat of arms of Portugal (Rosa, 2010: $160 \mathrm{ff})$. To these associations were now added the stigmata of Saint Francis in Monte Averno, considered by many to be God's mandate for the renovation of the Church of Christ. The alliance between these spiritual and temporal powers (Franciscans and the Kingdom of Portugal) was the pillar for the future coming of the reign of Christ. These parallels were particularly inspiring since Saint Francis was also considered the Angel of the Sixth Seal of the Apocalypse, the one who would bring together the Old and New Testaments, according to Ubertino di Casale in his Arbor Vitae (a book also transcribed in the Franciscan Chronica of Marcos de Lisboa).

For S. Thiago - like for Paulo da Trindade in his Conquista Espiritual do Oriente - these strong links between the Portuguese monarchy and the Franciscans were very explicit. Saint Anthony had been the first Portuguese overseas missionary, but also a representative (although S. Thiago does not explain how) of King Afonso Henriques and of Prince Afonso Henriques, born in 1643. Furthermore, the friars of Piedade had been intensively protected and supported by the Braganza family, and a hermitage dedicated to the Miracle of Ourique had already been built by Duke D. Jaime's time - the period when the modern account of the Miracle emerged. This hermitage was offered to the Franciscan friars, rendering material the links between Afonso Henriques, the Braganzas and the Franciscans.

In short: besides belonging to Portuguese providentialist traditions, Vizão feita por Xpo a el rey Dom Affonso Henriques was also a Franciscan providentialist treatise, a treatise where the links between the aspirations of the Portuguese monarchy and those of the Franciscans were clearly stated.

However, this treatise differed from other works written either in the Kingdom of Portugal or by Goan Franciscans such as Paulo da Trindade, Miguel da Purificação or Jacinto de Deos. This difference is related, on the one hand, to its frequent use of the real history of the Estado da Índia and of the rest of the Empire in the narrative (Vizão: fls. 75-88), and, on the other, to its greater integration of the non-Portuguese Indian world.

Adding to his various channels on information originating in Europe, and to his own "cosmopolitan" experience, other voices can be heard in his treatise which are, in my view, connected to S. Thiago's experience in India. Since these Indian contexts are important variables which may have affected the writing of the treatise, a brief examination of his life is necessary before advancing further with my hypothesis.

\section{ANOTHER CASE OF PORTUGUESE POLITICAL PROVIDENTIALISM IN AN INDIAN CONTEXT}

The biography of António de S. Thiago is mainly told by Jacinto de Deos in his Vergel de Plantas e Flores (Lis- bon, Miguel Deslandes, 1690: 389 ff, 396-399). ${ }^{10}$ Born in 1594 in Lisbon into a family said to have "noble origins", son of Feliciano de Carvalho Rodrigues, clerk of the House of India, S. Thiago went to India in 1612 as "a young man, with a handsome face and gallant manners". According to Deos, he was virtuous and patient, pious and courageous, but not intellectually gifted. He does not even refer to Vizão feita por Xpo, suggesting either that he was not aware of it, or that he considered it to be "dangerous". S. Thiago's treatise did not only skirt the borders of heresy, it was also favored by Afonso VI and Jacinto de Deos was writing at a time when D. Pedro had already substituted his brother in the Portuguese government. Jacinto de Deos and the friars of Mother of God were by this time strong supporters of the new political situation.

In 1612 , while still a lay person, $\mathrm{S}$. Thiago began to work for the king as a soldier, and was due to marry a Portuguese woman living in Goa. He was a contemporary of Pedro de Basto, the visionary Jesuit who he nevertheless does not cite and who merited a biography by Fernão de Queiroz (Biedermann, 2012). We do not know whether these two men crossed paths at any point; but we can say that both - as with other prophets, visionaries and even false Sebastians - shared the same space of early seventeenth-century Goa.

We do not know exactly why S. Thiago decided to become a Franciscan instead of marrying his betrothed. It was, however, common for soldiers afraid of losing their lives in the harsh military scenarios in the Estado da Índia to enter religious orders. From 1612 until 1660, when he died, S. Thiago remained in Goa, but he also travelled for some years to Chaul, in India, as well as to Malacca, in the eponymous strait connecting the Indian and Chinese worlds. We know very little about these two stays, but we do know a little more about his travels to Lisbon, Madrid and Rome, and through France, as Procurator of the Province/Custody of the Mother of God of India between 1624 and 1629.

After arriving in Lisbon in 1624, S. Thiago was imprisoned in the Convent of Saint Francis of Lisbon, which belonged to the Province of Portugal, the most important Franciscan province at the time. He was later released with help from his brother, who had inherited the office of clerk of House of India from his father, and of the legate Antonio Albergati. He then stayed in the Convent of Santo António dos Capuchos, in the province of Piedade, before travelling to Madrid, and from there to Rome. In Madrid he was again prosecuted by Franciscan authorities, and the same happened in Rome. In fact, his experience was in some ways similar to Friar Miguel da Purificação's, who came from the Province of Saint Thomas of India and who replicated some years later a trip with identical goals. These tensions were certainly provoked by the fact that only a Province could send a Procurator to Rome, and the institutional status of the Franciscans of Mother of God of Goa was still under dispute (Xavier, 2014b). Helped by an old acquaintance from Goa, a consistorial lawyer, he was re- 
leased for the third time. While fighting for the definitive recognition of the Custody of the Mother of God of Goa as an autonomous Province, S. Thiago was arrested again. He faced opposition from the General Minister of the Franciscans of the Province of Portugal, Friar Bernardino de Siena, and the General Procurator of the same Province, Friar João de S. Bernardino, the latter of whom would later write in support of the Braganza dynasty, too.

S. Thiago returned to Lisbon, embarking on his way back to Goa on the ship of Viceroy D. Miguel de Noronha, Count of Linhares. He arrived in 1629. While in Goa, S. Thiago was prosecuted by the General Commissioner of the Franciscans, Friar João de Abrantes, who exiled him to Malacca. He stayed there for around four years, eventually returning to Goa in 1633 . We have no information about the period between 1633 and 1640, but we know that in 1640 he was a Guardian of the Convent of the Mother of God of Goa, and later Provincial, also bearing the status of a preacher (1643-1646). In the 1650s, S. Thiago became General Commissioner of the Franciscans in India, and he died in 1660, one year after finishing the treatise.

As is evident from this brief biography, the author of Vizão feita por Xpo was completely engaged in the politics of the Franciscan order, and undoubtedly also played a role in the tensions that existed between the Provinces of S. Tomé of Goa (Observants) and of Mother of God of Goa (Recollects, a reformed branch of the Observants). Vizão feita por Xpo must be also read with the Franciscan context in mind. Furthermore, after being prosecuted and exiled, S. Thiago later climbed through all the positions of the cursus honorum of the friars established in the Estado da Índia, bearing witness to the disputes and internal changes within the Indian Franciscan community. But he was also a cosmopolitan man, born in Lisbon, and then travelling to India (living first in Goa and Chaul), then back to Europe (where he stayed in Lisbon, Madrid and Rome and travelled through France), then back to India, then to Malacca, and then back to India once again. All of these experiences and journeys, and the social and cultural interactions that came with them, had an instrumental effect in the formation of S. Thiago's worldview. Furthermore, just like other Franciscan "rising stars" like Paulo da Trindade and Jacinto de Deos, S. Thiago felt the need to leave a written statement. In his case this was not about the order (as it was for Paulo da Trindade), but about contemporary politics (as Jacinto de Deos would also later do with his Brachilogia de Principes [1670], dedicated to Prince D. Pedro [Lisbon: Miguel Deslandes, 1670]).

Like Jacinto de Deos, S. Thiago also appears to have been interested in the web of relationships between local and imperial politics. It is clear from what he writes about the status of the elites and general public in Goa that an important goal was to push Goa back up the list of priorities for the new Portuguese dynasty. He considered the decline of the Estado da Índia - a well-known and often-repeated topos since at least the end of the sixteenth century (Winius, 2001; Ferreira, 2011: $76 f f$ ) - to have been the result of the sins of the Portuguese, who treated the locals like "slaves" (Vizão: fl. 111). The vocabulary S. Thiago uses is very similar to that used, at exactly the same time, in Mateus de Castro's Espelho de Brâmanes. Castro, an Indian Brahman educated in the Franciscan order, had, like S. Thiago, been in Rome, but for a different reason - to fight against Franciscans from the Goan Province of São Tome (Xavier and Županov, 2015). Did S. Thiago and Castro meet there? Did they share their thoughts about other Franciscans, or about the Portuguese presence in India? Was S. Thiago defending, too, the interests of the converted Indians, a trace of Portuguese providentialism's characteristic inclusiveness (Vizão: fls. 110110v)?

$\mathrm{S}$. Thiago repeats an idea which had been intensively disseminated since at least 1640 , the idea that the inhabitants of the Estado da Índia were extremely loyal to the Portuguese king, and also clearly differentiates the colonized from the colonizer by stating that the Goan Portuguese were not of mixed blood. This was another typically creole topos, which had become very important among Franciscans of Portuguese origin and, indeed, among all the Portuguese in India (both those born there and those who had settled there), through which they tried to differentiate themselves from the local Indian population (thereby excluding them from any aspirations to "equality").

The eclectic range of topics covered in the treatise is a sign of the breadth and depth of the literature to which $\mathrm{S}$. Thiago had access. He combined these readings with other sources, such as conversations taking place in Goa at the time, stories he had been told, and manuscript treatises which were carefully circulated within a circle of interested people (these treatises included Sebastianist and other prophetic books). What is not yet clear is how S. Thiago used local Indian sources.

The Mughals are, of course, critical players when we come to this line of enquiry, and it is well-known that Akbar's, Jahangir's and Shah Jahan's courts were at the crossroads of several millenarist languages (Islamic, Indian and Western). The presence of, and interaction with, sages and scholars from a range of intellectual traditions was important in the forging of their millenarism and deeply connected to their politics. A few syncretic experiences can be identified in the Mughal court, symbolized most iconically in the figureof Dara Shikoh, and they were the result of the intense exchange of ideas that took place in the Mughal world (Ganeri, 2011; Subrahmanyam, 2012; Alam \& Subrahmanyam, 2013; Lefèvre, forthcoming). One of the strategies followed by Mughal rulers to forge their sacred kingship was to engage in intense activity with the Indian cultural world, namely combining traditional Indian myths with Islamic narratives and establishing parallels between the avatars of Indian Gods (namely Krishna and Rama) and Muhammad himself (Moin, 2012). 
Millenarist providentialism informed Abu'l Fazl's Akbar Nama, as it did several other narratives about Akbar's rule. In this work, Akbar is clearly depicted as the Emperor of the Messianic Age, the one who had the knowledge of God, the "perfect man". In fact, Akbar's government was closer to the first millennium of the Muslim era, which stimulated all kinds of millenarian associations, inspired by many Sufi ideologues who circulated in his court (Pirbhai, 2009). But millenarism is also present in Jahangir's autobiographical reflections in the Jahangir nama, a book which was disseminated throughout the Empire as a model of Mughal governance. Millenarism is not the main argument, but it is present when it is explained that Mu'inuddin Chishti, the most important twelfth-to-thirteenth-century Sufi saint, had passed his mission down to Jahangir. It was this Indian sage who had considered Jahangir to be the future "light of religion" and "the chosen one", and the transfer of his mission to the Emperor was completed by the latter's representation as the maker and renewer of peace around the world. In some authors' opinions, Jahangir moulded himself in such a way that he came to be simultaneously recognized as a political leader and a religious chief (Moin, 2012).

Iconography was one of the instruments used to spread these ideas. The images produced during Jahangir's reign combined Indian protocols with Islamic ones in order to expose selective political messages (Moin, 2012: 18, $85 \mathrm{ff}, 216)$. Symbolic elements, coming from the worlds of astrology, geomancy and dream interpretation, were used to convey this message. ${ }^{11}$ The transactions with Christian and Indian cultural issues were also expressed in some of these representations (Bayley, 1998; Koch, 2011; Flores and Silva, 2004; Carvalho, 2001; Moin, 2012; Subrahmanyam, 2012; Lefèvre, forthcoming), not only with regard to religious themes, but also - as Subrahmanyam has pointed out - embracing other visual forms, including atlases and globes, motifs taken from geographical maps, and even painting techniques (Koch, 2012; Subrahmanyam, 2012). Parallel processes were going on in the Rajput principalities and Deccan sultanates, which were by no means unaware of what was happening in the Mughal Empire. Intercultural exchange was intense.

As well as the differences which can be identified in this rich world of Indian painting, there were also many common elements, namely the way in which drawings and paintings were frames, frequently ornately decorated using plant motifs (for a general view, see Michell, 1995; Michell and Zebrowski, 1999; Haidar and Sardar, 2015).

I now attempt to identify the ways in which this Indian visual world is depicted in S. Thiago's treatise, bearing in mind that the combination of these topoi - the idea of transmission of power from the saintly world to the earthly one, of the "chosen one", of the "renewer" - and the ways in which images could transmit them, was very familiar to the Portuguese early modern world, at least from King Emmanuel onwards.-
Recent literature has demonstrated that the territories of Goa, part of the Western Deccan territories of India, were also at the crossroads of intense processes of social and cultural exchange. Rosalind O'Hanlon and Christopher Minkowski's essay on the identity of Brahmans from the Deccan territories is quite explicit about the networks that connected the Brahmans of Goa with Brahmans settled in the Deccan sultanates (O'Hanlon and Minkowski, 2008). Such openness was certainly expressed in the inner life of the non-Christian inhabitants of Goan territories, even if little is known, still, about these people's experiences apart from those of the "usual suspects" - merchants, rentiers, and other groups with financial interests. However, Goan life took place beyond the financial and economic elites who had close relations with the Portuguese government in Goa.

1526 and 1700 are two interesting chronological bookends which we can use to consider the persistence of this "other life". The first refers to the year when Krishnadas Shama, of the village of Keloshi in Salcete, finished his history of Krishna, Krishna charitra katha. This was some time before those territories were annexed by the Portuguese (that happened in 1543). The second refers to the Goan version of the Sahyadri Khan$d a$, a narrative which Goans claimed was part of the Skanda Purana, the classical purana which described the foundation of Goan lands. Providentialist topics structured both texts, and traces of providentialist political imagination can also be identified in the Goan version of the Ramayana, in which some episodes explained that the territories had been chosen by Rama (an avatar of the Indian god Vishnu) as his homeplace. Rama brought with him Goan Brahman families, who depicted themselves as a kind of "elected people". Myths related with Krishna, Rama and Purusurama were "Goanized" and "territorialized", turning Goa into a "chosen place" and the Goans into a "chosen people" (Gomes, 1996 and 1999; Cunha (ed.), The SahyadriKhanda, 1877). Providentialist topics were also present in other "Goan" writings, namely those by the Catholic Brahman António João Frias and the Catholic Chardo Leonardo Paes. In both Aureola dos Indios, Nobilarchia Bracmana (Lisbon: Miguel Deslandes, 1702) and Promptuario de Diffiniçoes Indicas (Lisbon: Antonio Pedroso Galrão, 1713), God had chosen a particular group to embody the most noble and Christian virtues: for Frias, the Brahmans, and for Paes, the Chardos.

The synchrony between these Indian and Portuguese providentialist languages is striking. Were there any connections between both? Or were these two parallel languages, without any contact?

My answer to the latter question tends towards the negative. We can discuss these Catholic languages within a strict Catholic/European world, as Biedermann did in his fascinating essay on Pedro de Basto and Fernão de Queiroz's millenarism (Biedermann, 2012), but we can also consider their porosity to the Indian world. In fact, we do know that cultural exchanges of all types did exist between Catholics and non-Catholics. Diplomats, mer- 
chants and soldiers are well-known intermediaries, but Catholic and non-Catholic scholars and theologians also engaged in serious intellectual exchange and debate, many of which involved Jesuit (Županov, 1999) and Franciscan missionaries. In fact, Friar Paulo da Trindade refers in his Conquista Espiritual do Oriente that Franciscans had their own dialogical experiences with Indian Brahmans, and that in his treatise he did not discuss in length Indian topics because that was not the goal of his work (Trindade, 1962, I; Xavier \& Zupanov, 2015). Like him, other Franciscans undoubtedly had their local "informants", as the versions of Christian books in Indian languages written by missionaries of Estado da Índia clearly testify.

In the case of the treatise in question in this essay, I would like to argue that while topics in the written narrative point towards a dual inspiration, it is in the visual text that this hybridism is more explicit, turning this document into a unique witness of the cultural exchanges taking place in early modern Goa.

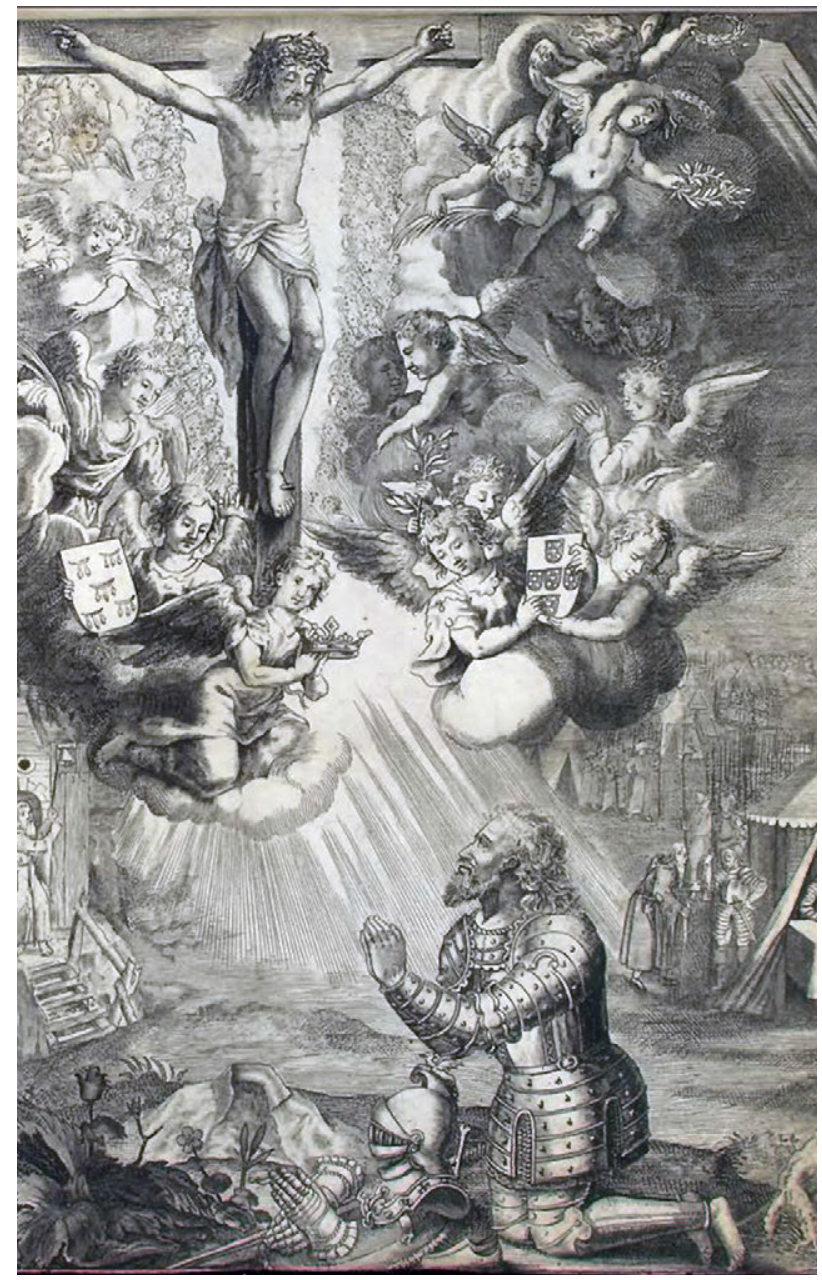

Figure 3. António Soares de Albergaria, Tropheos Lusitanos, 1632.
It is clear that the artist received precise indications from Friar Antonio de S. Thiago, or someone else, to use Portuguese images in circulation in the Goan world, arriving undoubtedly from the Kingdom. ${ }^{12}$ The image of the Miracle of Ourique makes this quite evident. Clearly, its immediate inspiration was the print image included in the publications of Iuramento com que ElRey Dom Afonso Henriquez confirmou a visão de Christo nosso Saluador (Lisbon: António Álvares, 1641), the main "historical" source used by Friar Antonio de S. Thiago; the published version of Fernão Lopes' Chronica delRey D. Joam I (Lisbon: António Álvares, 1644), and Pedro de Sousa Pereira's treatise Mayor Triumpho da Monarchia Lusitana (Lisbon: M. da Silva, 1649). All were based, in turn, on a more sophisticated image by Agostinho Soares, published in António Soares de Albergaria's Tropheos Lusitanos (Lisbon: Jorge Rodrigues, 1632), which became the model for subsequent books and prints published during the Portuguese "Restoration" (Figs. 3-6) ${ }^{13}$

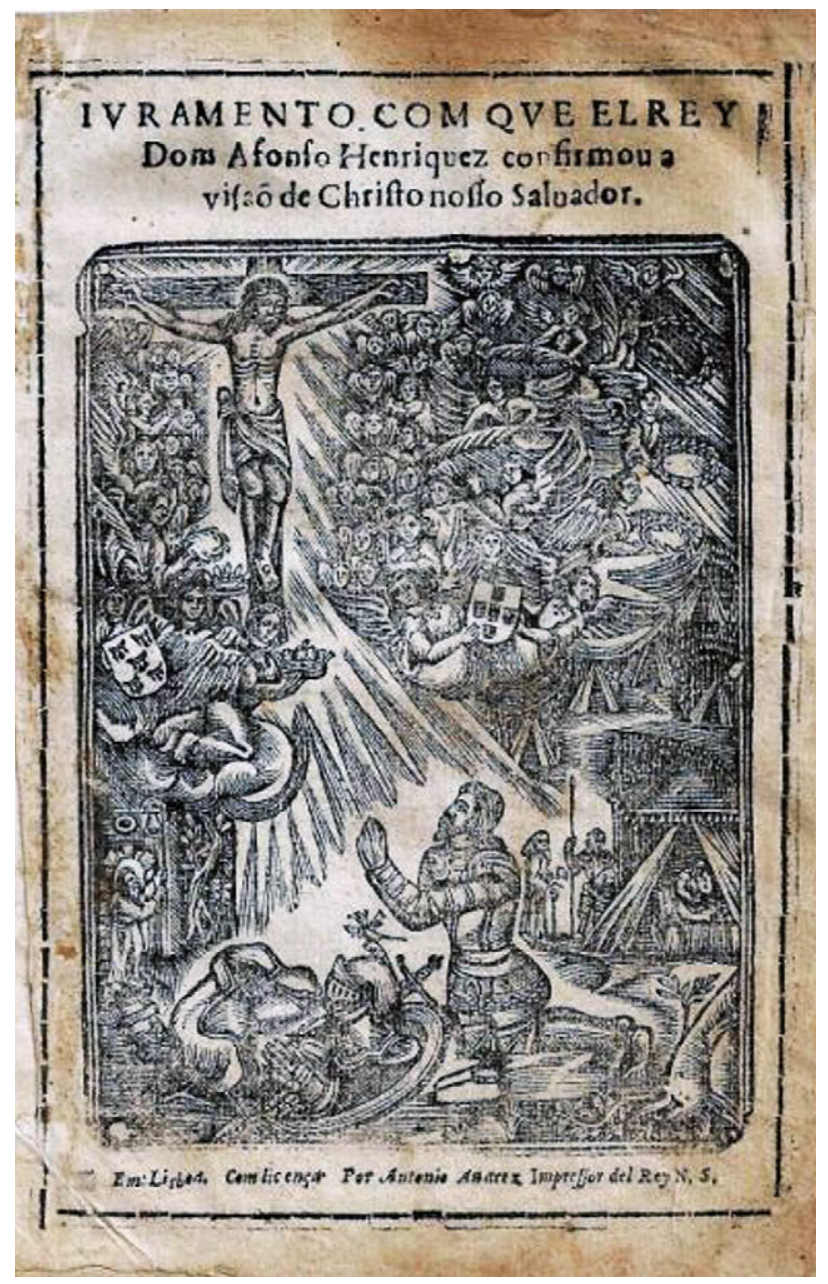

Figure 4. Iuramento com que Elrey Dom Afonso Henriquez confirmou a visão de Christo nosso Salvador, 1641. 


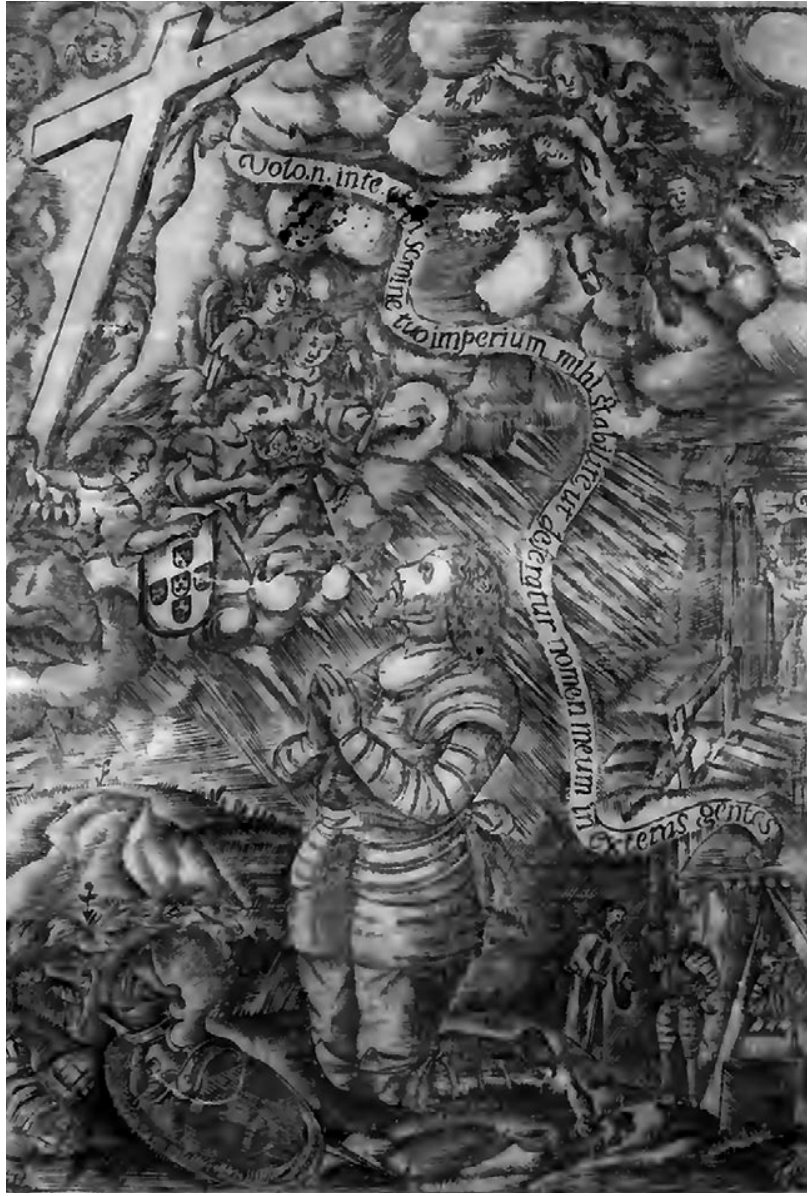

Figure 5. Pedro de Sousa Pereira, Mayor Triumpho..., 1649.

Each one of these images has a similar dispositio and uses similar motifs, even if the quality of the drawings is not comparable. Furthermore, the transition from the printed image (figs. 3-5) to the manuscript (fig. 6) allowed some creativity, both in the ways features like the stars and the hurricane were included in the depiction and in their aesthetic presentation. In particular, the framing of fig. 6 differs from usual European depictions of the Miracle of Ourique, and from other images of this period more generally. On the contrary, as discussed below, this type of framing (which reappears in the majority of the images of this treatise) was typical of Indian miniatures. Further differences can be seen in the interior of the image: the inclusion of stars, a scepter and a crown in an angel's hands, held out to the King (there are therefore two crowns in the image); the location of the friar who is calling from the right-hand side; and a hurricane appearing at the same time as Christ pronounces his prophetic statement: Volo enim in te, ut in semine tuo imperium mihi stabilire ${ }^{14}$. Vision, evocation of orality, and written word converge in order to create a more performative image. What do pictures want?, asked W. J. T. Mitchell in his inspiring book of the same title (Mitchell, 2005); the same can be asked in relation to this image and the others in S. Thiago's treatise: what did they really want?

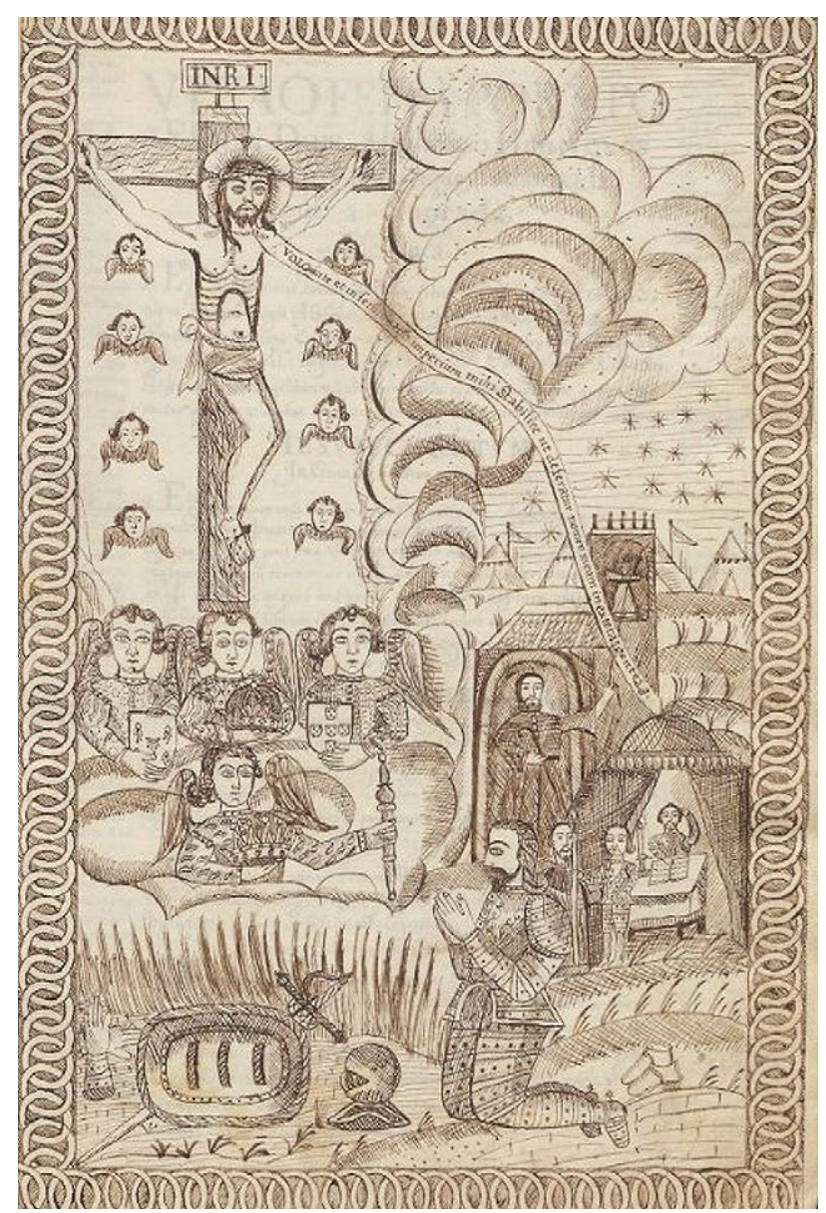

Figure 6. Antonio de S. Thiago, Vizão..., Harvard University, Houghton Library, Ms Port 4666, fl. 3.

They certainly wanted something which differed from the images they imitated. Like certain Indian images, they sought to produce a feeling of wonder, something which one still feels when stumbling upon this manuscript. They seem to have wanted to escape from strict artistic protocols, protocols which - for depictions of Ourique, for example - had been present since the very first images, namely in the Genealogia do Infante D. Fernando, produced between 1532 and 1534. These, the first Portuguese images of the Miracle of Ourique (produced by António de Holanda and Simon Bening), were probably inspired by existing depictions of miracles and visions, specifically the most famous vision of the medieval period, Saint Francis of Assisi receiving the stigmata, as first depicted by Giotto. Even though this theme had been reactivated and changed by sixteenth- and seventeenth-century Italian painters like Titian, Carracci and Caravaggio among others (Askew, 1969), it is the structure of Giotto's depiction which appears to be paradigmatic for that of Afonso Henriques' vision from the sixteenth century onwards. Like in images of Saint Francis, the King in depictions of the Miracle of Ourique is always on his knees, looking up to the apparition in the heavens and with his hands clasped in prayer. In both depictions, furthermore, the heavenly figure is suspended in the sky at an oblique angle, showing a clear desire to com- 
municate with the earthly beings. Finally, rays of light connect the heavens to the earth, the angel and Christ to Saint Francis and Afonso Henriques (figs. 7 and 8). ${ }^{15}$

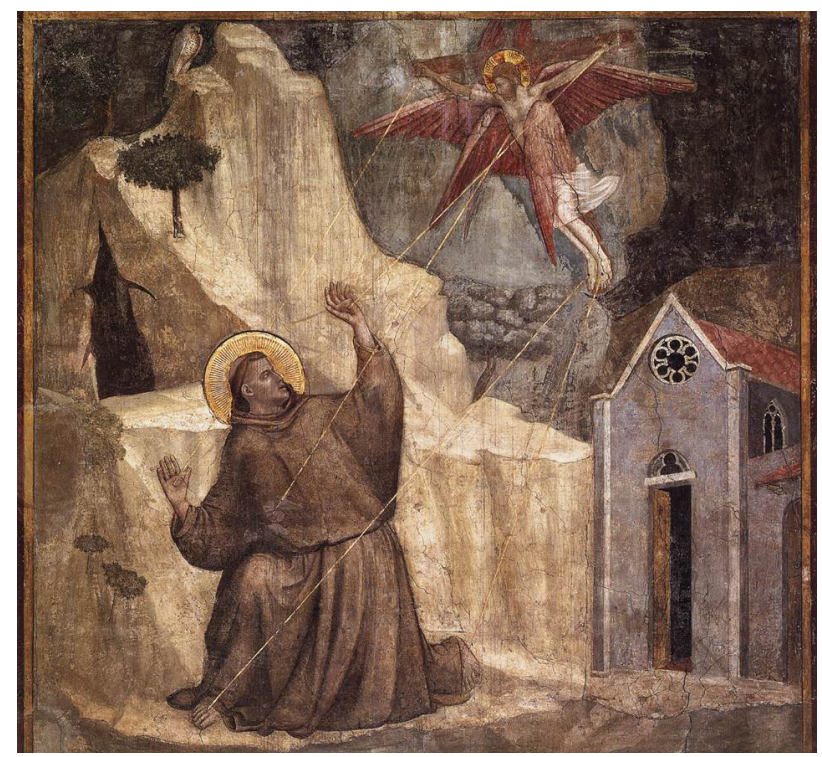

Figure 7. Giotto, "Stigmata of Saint Francis of Assisi", fresco in the upper Basilica di San Francesco di Assisi.

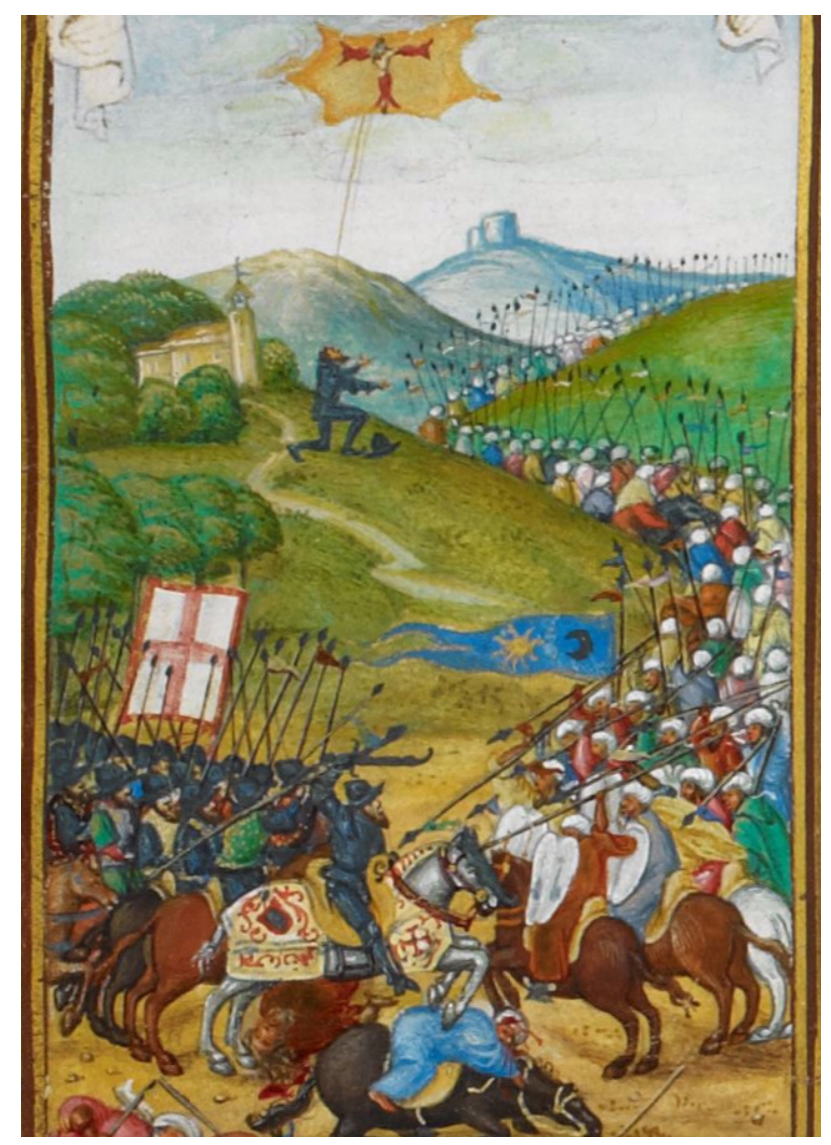

Figure 8. Detail of "Tavoa primeira dos Reys de Portugal", Genealogia do Infante D. Fernando (BL, Add.. 12531, fls. 7-8).
If the connection between Saint Francis and Afonso Henriques is indeed present, we should consider a "Franciscan inspiration" (if not a "Franciscan matrix", not yet at least) to visual narratives of Ourique, linking, from the very beginning, the experiences of the founding father of the Portuguese monarchy and the founding father of the Franciscan order.

This Franciscan-European matrix, if it exists, is complemented in this case by an Indo-Persian one. In fact, the mobility of these images, travelling from Portugal to India, and their reproduction in an Indian context (and by an Indian artist), could have unintended consequences. Besides the framing and some iconographic motifs already present in the image of the miracle, other analogies are also striking, revealing that the author of these images was an imaginative but not very skilled Indian painter, probably a converted Goan (figs. 9-13).

\section{(6)}

FIGURE 9. Detail from the framing of Afonso Henriques in Vizão de Affonso Henriques, Harvard University, Houghton Library, Ms Port 4666, fl.

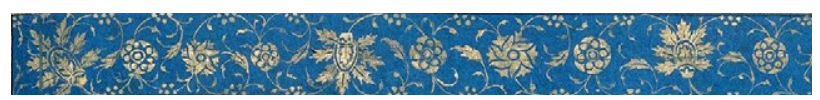

FIGURE 10. Detail from the framing of Shah Jahan on a terrace, holding a pendant, Metropolitan Museum of Art, Accession Number: $55.121 .10 .24-\ldots$

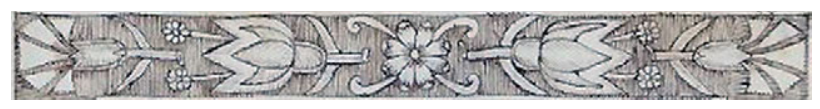

Figure 11. Detail from the depiction of King Emmanuel in Vizão de Affonso Henriques, Harvard University, Houghton Library, Ms Port 4666.

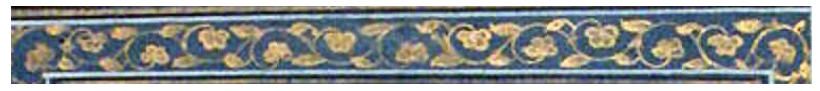

FIgURE 12. Detail from the framing of Jafal Khan, Metropolitan Museum of Art, Accession Number: 45.174.13.

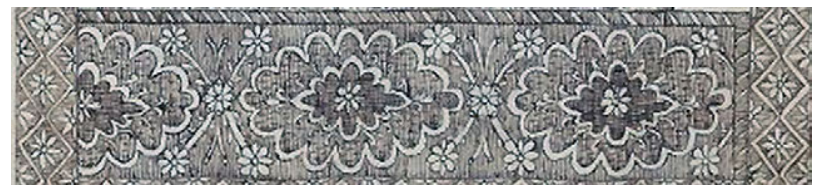

FIgURE 13. Detail from the framing of Afonso VI in Vizão de Affonso Henriques, Harvard University, Houghton Library, Ms Port 4666. 
These details from the framings of other images in the manuscript and of some Indian miniatures show how Indian aesthetics were incorporated into their decoration, recalling what we find in other, better-known, material objects such as chairs, portable chapels, containers of all sorts, and so on. Indian aesthetics were also clearly incorporated into the decoration found in clothing, tapestries, and the representation of angels. All of them are reminiscent of Indian painting, either from an earlier period - the sixteenth century - or from the same decades and from neighboring courts (for an overview of this painting see Haidar and Sardar, 2015).

Furthermore, the way in which the human figures are drawn, namely the figuration of the face, eyes and nose, leave little room for doubt that such iconographic motifs were culturally mobile. The portrait of Jafar Khan, of the $17^{\text {th }}$ century (fig. 16), is suggestive enough when compared to the depictions of Christ and of Afonso Henriques in S. Thiago's treatise, from 1659 (figs. 14-15). It is unquestionable that the non-Goan painter of Jafar Khan was more sophisticated than the Goan one, but it is also true that the protocols of portraiture were similar in the following three cases.

These parallels are identifiable in some of the formal choices made by the artist in S. Thiago's treatise, but they do not end there. Links might be established between some of the topoi that structure this treatise and classical Indian mythology; the cases of the sacred gaze, on the one hand, and of the dreams of Vishnu, on the other, immediately come to mind, contaminating, possibly, the meanings behind the depictions of Christ and of kingship in S. Thiago's treatise.

As noted above, it is impossible to address these topics in a complex and truly comparative way in such a short essay. However, it would also be unwise not to refer, even if no more than schematically, to the role of daršan - the gaze of the divine image - in the Indian world, and the possibility that the conception of daršan might have contaminated the ways Christ was represent- ed, and the meanings of the direct, visual communication between God and humankind which transpire from S. Thiago's treatise.

In her fascinating book, Diane Eck defines daršan as the "auspicious sight of the deity". "To see and to be seen by the deity" was crucial in Indian forms of worship, a cultural practice that was not completely different from early modern Catholic culture (bearing in mind, naturally, all the controversies around the value of the "sacred" images that took place in this period [Eck, 1998: 3, 104]). The centrality of the image in the Catholic world, about which much ink has been spilt over the years, was viscerally true for the (Goan) Franciscans, who considered their own exemplary behavior - and the way it was seen and experienced by others - as the best instrument of evangelization and conversion (Purificação, 1641). Differentiating themselves from more "intellectual" orders, such as the Dominicans and the Jesuits, deeply concerned with the transmission of the word, each Franciscan was an image of God, aspiring to be another alter Christus, as Saint Francis had once been.

Besides assembling typical Christological iconography, and besides evoking typical motifs present in, for example, Portuguese historical tiles, can the following depiction of the cross (fig. 17) also be seen to evoke Siva Nataraja, the Lord of the Dance? Indeed, the depiction of the face of Christ is very reminiscent of the majority of the depictions of Śiva Nataraja, such as the half-open eyes, looking down, and the beatitude of the face with its hidden and benevolent smile (Zimmer, 1997: 156 ff, 175). Or is it, rather, a free combination of iconic motifs, framed by the typical garland of the Indian devotees, namely the ones who followed the bhakti movement (or could the frame evoke, alternatively, a necklace typical of Viana do Castelo or the garlands present in Portuguese wall tiles and in several paintings of Christ)? In the first case, some iconic themes could have been extolled from their spiritual meanings, incorporating new motifs, like the seven eyes wide open staring at us. Adding to the

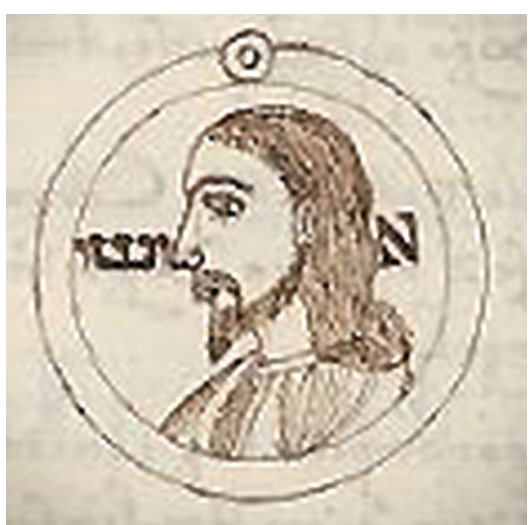

FIGURE 14. Depiction of Christ in Vizão..., Harvard University, Houghton Library, Ms Port 4666, fl. 157.

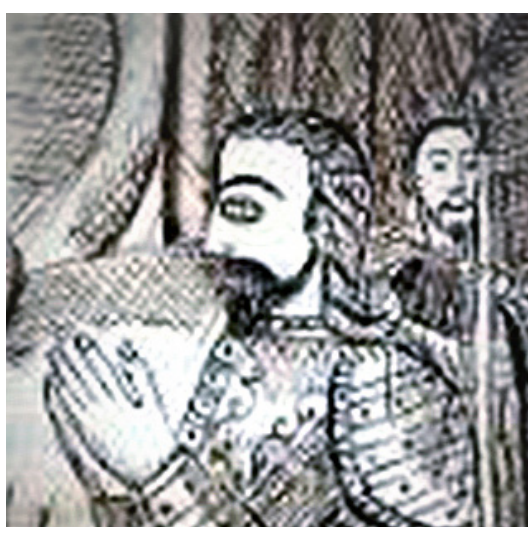

Figure 15. Detail of Afonso Henriques in Vizão... Harvard University, Houghton Library, Ms Port 4666, fl. 3. de Affonso Henriques, fl.

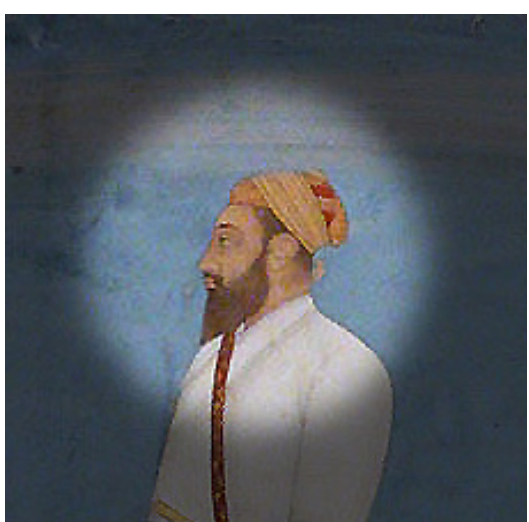

FiguRE 16. Detail of the depiction of the portrait of Jafar Khan, $17^{\text {th }}$ century, Metropolitan Museum of Art, Acc. Nr. 45.174.13. 


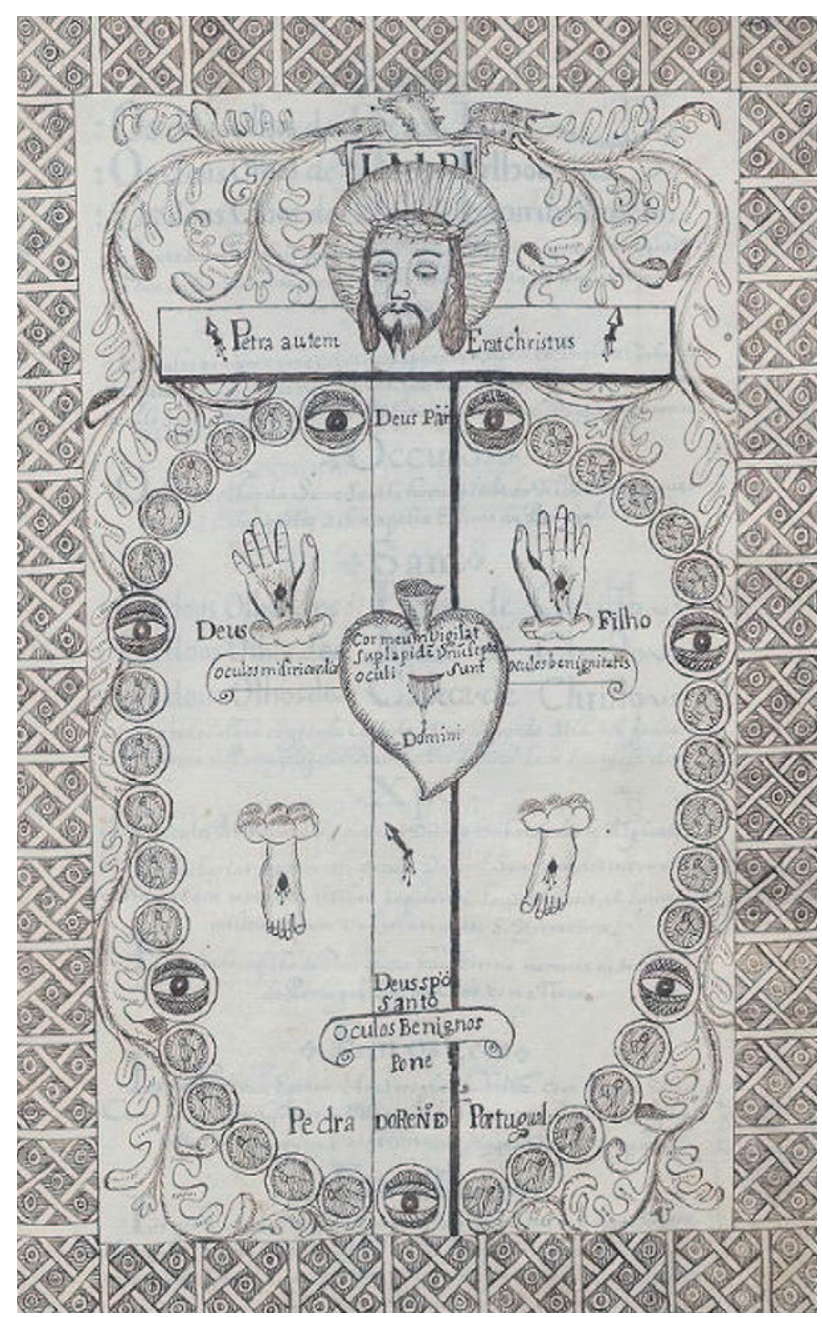

Figure 17. "Tarja dos olhos" in Vizão..., Harvard University, Houghton Library, Ms Port 4666, fl. 47.

symbolic meaning of the number seven, S. Thiago labelled this image as "tarja dos olhos" ("image of the eyes"), reminding us of that "auspicious sight of the deity" (the Indian deity, of course). However, if the influence is less structural, then we may simply face a mixture of Christian and Indian motifs, producing, in any case, a visual blend that is difficult to find in a strictly European context.

Let me consider, in order to finish this digression, the image of Afonso VI in 1659, the year he was supposed to accede to the throne, as it appears in S. Thiago's treatise, and the famous miniature representing the Emperor Shah Jahan on a terrace holding a pendant (figs. 18 and 19).

Again, the image of Afonso VI (fig. 18) combines classical topoi of Portuguese kingship portraits, such as the table on the side (here with crown perched on top), with a depiction in the Indian style. Indeed, Afonso VI stands under a structure which evokes the Mughal darbar of other Mughal emperors' portraits (such as that of Shah Jahan with his sons). Furthermore, he stands on top of another structure, richly decorated, with Persian-style car- pets and Indian motifs that evoke the Persian takht, which again was very common in Mughal depictions of kingship. Finally, if we consider the visual narrative of the treatise, the portrait of Afonso VI is the richest of all the portraits of kings.

Could this be a visual strategy to reinforce the argument in favor of Afonso's royalty, contested by many due to his physical (and perhaps mental) disabilities? What is certain is that $\mathrm{S}$. Thiago and this artist made a conscious decision to inflate Afonso's image, and the best way they found to do it appears to have been to imitate depictions of the most powerful of all Indian princes: the Mughal emperor (fig. 19).

It is not possible to say with certainty that there was direct cultural exchange between, on the one hand, the scholars and painters circulating in the Mughal court and, on the other, the Goan Franciscans of the period; we know much more about the Jesuit versions of this cultural transfer (Bayley, 1998). But we do know that Franciscans circulated in the Mughal court; Friar Paulo da Trindade's Conquista Espiritual do Oriente has a full

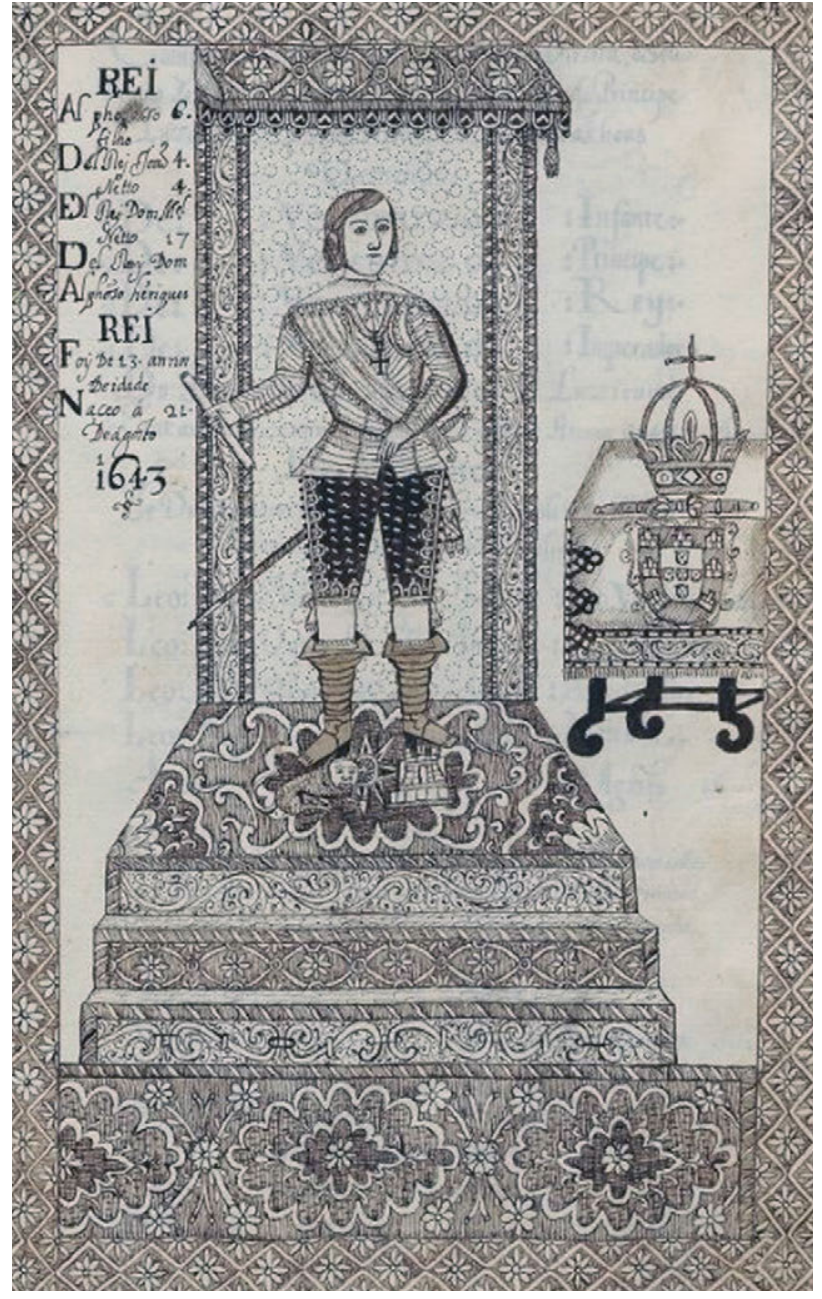

Figure 18. Afonso VI in Vizão..., Harvard University, Houghton Library, Ms Port 4666, fl. 55. 


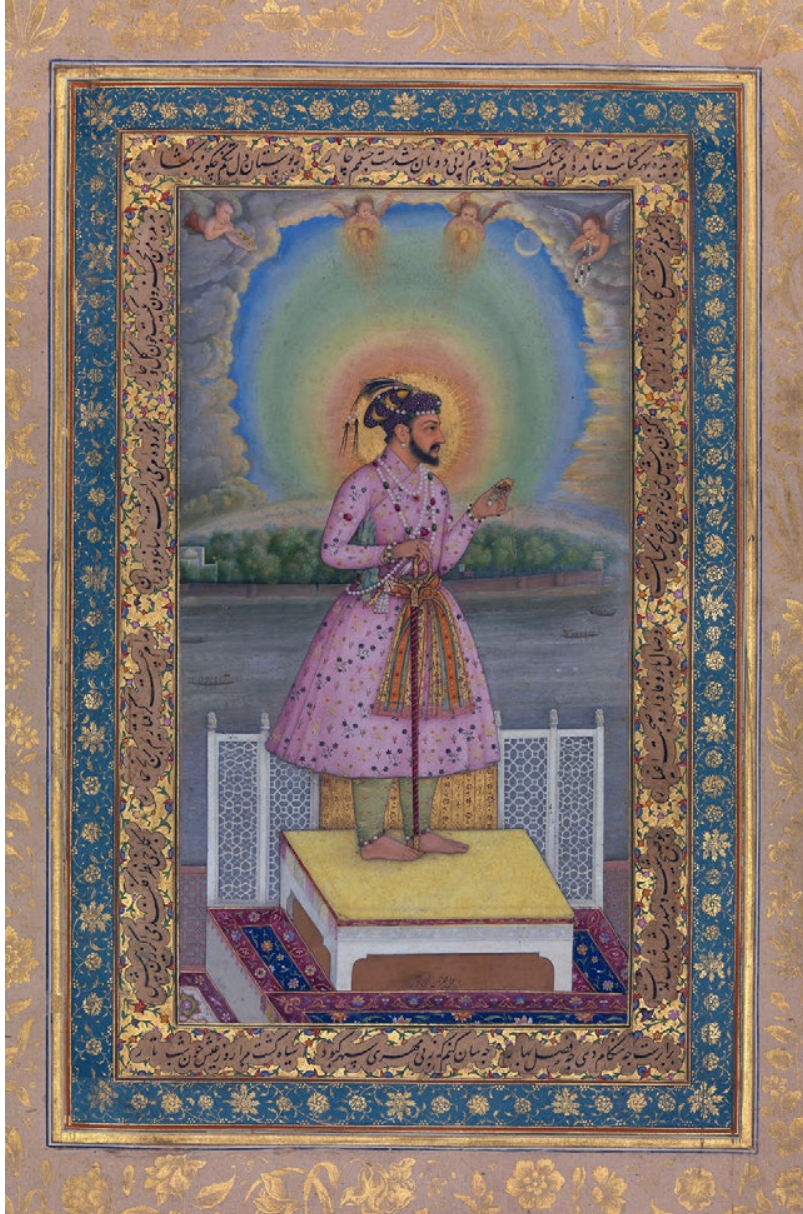

FIGURE 19. Shah Jahan on a terrace, holding a pendant, Metropolitan Museum of Art, Accession Number: 55.121.10.24

chapter on Franciscan missions up to 1636 (when his treatise was written), and Jesuit annual letters from 1624 also refer to the Franciscan presence in the Mughal court in 1623 and 1624. From these narratives, we know that these particular Franciscans had been well received by the Jesuit priests' mission, and interacted directly with Jahangir, albeit in a much bolder way than the Jesuits, leaving after they realized that Jahangir's conversion was an illusion (Camps, 2000; Trindade, 1964: 4251). Some of these narratives refer to the exchange of gifts between the Franciscans, who brought an image of the Mother of God to the Mughal Emperor, and Jahangir. Did they have the opportunity to see miniatures like this one? Possibly, but these narratives insist more on a refusal of the Mughal court's riches (a typical Franciscan topos) than on any fascination with its sophistication. More probable is that the wide circulation of these images in the courts surrounding Goa, and perhaps in Goan workshops too, explains why the painter of the images in S. Thiago's treatise adopted some of their stylistic features and even - perhaps for purely aesthetic reasons - some of their contents.

\section{CONCLUSION}

This line of research should be pursued in order to provide more detailed information about these types of cultural exchange, and the ways in which they influenced Portuguese cultural objects beyond the better-known areas of carpets, textiles, paintings, sculptures, ivory carvings and religious and urban architecture. Furthermore, these objects could have inspired the illustrator of S. Thiago's treatise. Since it has been impossible to explore the exchanges between material objects and written treatises, I have merely shared some impressionistic thoughts and observations which allow me, in any case, to draw a sort of conclusion, albeit a risky one.

In this essay I have argued three different things. The first argument, that Friar Antonio de S. Thiago's treatise is fully engaged with early modern Portuguese intellectual and political dynamics, was clearly demonstrated in the first pages. Vizão feita por Xpo a el rey Dom Affonso Henriques forms part of the political providentialist dynamic of the period, which means that in-depth study of the legitimization of the Braganza monarchy implies a need to investigate literature produced extra territorium, namely in the Estado da Índia. I believe that this exercise will also contribute towards a more complex version of the Atlantic and Jesuitic matrix which inspires the majority of current scholarship.

A second argument, following the work of José Adriano de Carvalho and Maria de Lurdes Rosa, is that we must study in detail the role of the Franciscans in early modern Portuguese historical processes, and consequently, in the history of Portuguese political languages. Adding to its identity as a typical Braganza-legitimist treatise, S. Thiago's work was also a Franciscan providentialist treatise. The association between Afonso Henriques and Saint Francis, and between the history of the Portuguese kingdom and the history of the Franciscan order, and the benevolent protection of Christ to both, were typical Franciscan topoi that structured this treatise. How did associations like this disseminate in the Kingdom of Portugal, where there was a dense network of Franciscan churches and convents (and people) in both the rural and the urban worlds? And what was its role in an empire where the Franciscan presence was statistically comparable to the Jesuit one? These are both questions which deserve further attention.

S. Thiago's treatise is set apart from Franciscan treatises written in the metropolitan world because one of its aims was to push Goa back up the list of priorities for the new dynasty. Challenged by the growing importance of the Jesuits in the Portuguese court, who could not, by any means, claim as old a relationship to the Portuguese crown as the Franciscans could, the political context of 1640 was also seen as an opportunity to re-establish the former Franciscan hegemony.

My third argument is interconnected with the treatise's production in the territories of Goa: this treatise was also a hybrid object, a witness of the cultural transactions that took place at a cultural crossroads like Goa. There- 
fore, the situation and events of the period in Goa, as part of the Indian cultural world, should also be taken into account, as other scholars have already argued, in the study of early modern political ideas and practices —and not only when studying, for example, material objects, as art historians have already done.

Regrettably, as noted above, space constraints have meant that several relevant aspects and themes have been left untouched, including Franciscan-Jesuit antagonism, and the more general problem related with the circulation and reception of this treatise. Another is the cabalistic nature of the treatise which pushes it very close to heterodoxy and makes it a "borderline" treatise; another is a deep discussion of its world of images. I hope to discuss these issues in a subsequent essay.

\section{ACKNOWLEDGEMENTS}

I am extremely indebted to many colleagues and friends for their suggestions, comments, and bibliographical help while I was thinking about and writing this article: António Camões Gouveia, Cícero Pereira, Corinne Lefèvre, Father José Tolentino de Mendonça, Federico Palomo, Fernanda Olival, Fernando Bouza, Ines Županov, Luís Filipe Silvério Lima, Maria de Lurdes Rosa, Miguel Metelo de Seixas, Nuno Senos, Pedro Cardim, and Sanjay Subrahmanyam. I also want to express my gratitude to Matt Stokes for reviewing it so carefully. Any errors, limitations or omissions are, of course, my own. This study has been undertaken as part of the projects Letras de frailes: textos, cultura escrita y franciscanos en Portugal y el Imperio portugués (siglos XVI-XVIII) HAR2011-23523; and Imperios de papel: textos, cultura escrita y religiosos en la configuración del Imperio portugués en la Edad Moderna (1580-1668) - HAR201452693-P. Both are funded by the Spanish Ministry of Economy and Competitiveness.

\section{NOTES}

1 S. Thiago, Antonio de, Vizão feita por Xpo a el rey Dom Affonso Henriques no Campo de Ourique, 1659, Harvard University, Houghton Library, Ms Port 4666. Subsequent citations will use only the shortened Vizão and the respective folio(s). When this essay was ready to be published, my colleagues Urte Krass and Jeremy Roe (who is doing research on this) told me about a treatise called «Episódios Da História de Portugal E Várias Lendas E Profecias Com Ela Relacionadas», conserved in the Arquivo Nacional da Torre do Tombo, in Lisbon, which has been written by the same friar. This treatise also includes some of the images that are included in «Vizão feita por Xpo...». Unfortunately, at this moment it is not longer possible to analyse s other treatise in relation to the one that is object of this text.

2 For Franciscans in the Estado da Índia see Xavier, 2008 and Souza, 2013, and the bibliographies cited in those works.

3 In that sense, these writings could be compared to similar writings produced by Franciscans in the Spanish Atlantic colonies, for example to identify shared topic matter.

4 I would like to thank Luís Filipe Silvério Lima for reminding me of this important aspect.

5 The best work on the myth of Ourique is still Ana Isabel Buescu's (Buescu, 1987). Previous bibliography can be found there; for a later period, see Luís Filipe Silvério Lima (Lima, 2010).
6 The bibliography on Sebastianism is enormous, and can be consulted in Mendonça and Valdez (Mendonça, 2004; Valdez, 2010)

7 See Carolino, 2002; also Xavier and Cardim, 2006. S. Thiago refers to many prophecies favorable to Afonso VI, but also which interpret his physical problems as a divine sign (namely, a diary written in Lisbon and sent to Goa bearing this information).

8 Gaspar Sinel was a captain who travelled between the Atlantic and the Indian worlds. Apparently, his book circulated among Goan elites, and around 1659 it was with António Gil Preto, judicial official of Estado da India, as well as its official chronicler after Bocarro (Vizão, fl. 158); Amaro Moreira Camello was a knight of the Order of Christ, who lived in Portugal, Castile and Goa, where he wrote, between 1652 and 1654, the third and fourth parts of the genealogy of the Mascarenhas family (Machado, 1741-1759, I, : 126-127).

9 The full catalogue of biblical references includes: Ezra, Isaiah, Daniel, Proverbs, Psalms, Apocalypse, Jeremiah, Matthew, Genesis, Leviticus, Exodus, Numbers, Ecclesiastes, Luke, Mark, Acts, Augustine, Ezekiel, Zechariah, Wisdom, Deuteronomy, the Epistle of John and the Epistle of St Paul to the Romans.

$10 \mathrm{He}$ appears as an author neither in Diogo de Barbosa Machado's Bibliotheca Luzitana (Lisbon: Isidoro da Fonseca, 17411759, I) nor in Juan de San Antonio's Bibliotheca Universa Franciscana (Salamanca: Typographia Causae V. Matris de Agreda, Madrid: 1732).

11 Luís Miguel Carolino and Rui Capelo have demonstrated in a very incisive way the structuring presence of these aspects, too, in early modern Portugal (Capelo, 1994; Carolino, 2002).

12 However, there are no traces of inspiration from Francisco de Holanda's Aetatibus Mundi Imagines, a treatise which, as José Adriano de Carvalho has noted (Carvalho, 2004: $77 \mathrm{ff}$ ) translated into mimaged many topoi taken from the Apocalypse of Saint John and Ubertino di Casale's Arbor Vitae. Friar Antonio de S. Thiago was familiar with both of these treatises, but there are no traces that he knew their previous visual representation.

13 I am grateful to Miguel Metelo Seixas and Fernando Bouza Álvarez for having shared with me some of these associations.

14 "For I want to found my kingdom in you and your descendants".

15 Surprisingly, it was not the drawing of the miracle present in the Genealogia do Infante D. Fernando, by António de Holanda and Simon Bening, of the first half of the sixteenth.century that inspired the most successful representations of the "vision" of Afonso Henriques.

\section{REFERENCES}

Alam, Muzzafar (2004) The Languages of Political Islam in India, c. 1200-1800. Permanent Black, Ranikhet.

Alam, Muzzafar and Subrahmanyam, Sanjay (2013) Writing the Mughal World: Studies in Culture and Politics. Columbia University Press, New York.

Askew, Pamela (1969) "The Angelic Consolation of St. Francis of Assisi in Post-Tridentine ItalianP ainting". The Journal of the Warburg and Courtauld Institutes, 32: 280-306.

Aurell, Martin (1997) "Messianisme royale de la couronne de Aragon, 14e. et 15e. siècles". Annales. Histoire, Sciences Sociales, 52 (1): 119-155.

Babayan, K. (2002) Mystics, Monarchs and Messiahs. Cultural landscapes of Early Modern Iran. Harvard University Press, Cambridge, Mass.

Bang, Peter Fibiger and KoŁodziesjczyk, Darius (eds.) (2012) Universal Empire. A comparative approach to Imperial Culture and Representation in Eurasian History. Cambridge University Press, Cambridge.

Bayley, Gauvin (1998) The Jesuits and the Grand Mogul: Renaissance Art at the Imperial Court of India, 1580-1630. Occasional Papers, nr. 2, Freer Gallery of Art, Washington DC. 
Bethencourt, Francisco (2007) "The political correspondence of A1buquerque and Cortes". In Correspondence and Cultural Exchange in Europe, 1400-1700, edited by Bethencourt, Francisco and Egmond, Florika. Cambridge University Press, Cambridge.

Biedermann, Zoltán (2012) "Um outro Vieira? Pedro de Basto, Fernão de Queiroz, e a profecia jesuítica na Índia no século XVII". In António Vieira e o Universalismo dos séculos XVI e $X V I I$, organized by Sabbatini, Geatano and Cardim, Pedro. CHAM, Lisbon: 145-173.

Bouza, Fernando (2001) Corre manuscrito. Una historia cultural del Siglo de Oro. Marcial Pons, Madrid.

Brady, Andrea and Buttersworth, Emily (eds.) (2010) The Uses of the Future in Early Modern Europe. Routledge, London.

Buescu, Ana Isabel Carvalhão (1987) O Milagre de Ourique e a História de Portugal de Alexandre Herculano. $1^{\text {st }}$. edition. Instituto Nacional de Investigação Científica, Lisbon.

Camps, Arnulf (2000) "Franciscan Missions to the Mogul Court". In Studies in Asian Mission History: 1956-1998, edited by Arnulf Camps. Brill, Leiden: 60-74.

Capelo, Rui Grilo (1994) Profetismo e Esoterismo. A arte do prognóstico em Portugal (secs. XVI-XVIII). Minerva, Coimbra.

Carolino, Luís Miguel (2002) A escrita celeste: almanaques astrológicos em Portugal nos séculos XVI e XVII. Access, Rio de Janeiro.

Carvalho, José Adriano de Freitas (1994) "Achegas ao estudo da influência da Arbor Vitae Crucifixae e da Apocalypsis Nova no século XVI em Portugal”. Via Spiritus, 1: 55-109.

Carvalho, José Adriano de Freitas (1991) "Profetizar e conquistar em Portugal dos fins do século XV a meados do século XVI. Introdução a um projecto". Revista de História, 11: 65-94.

Carvalho, José Adriano de Freitas (1999) "Benfeitores dos franciscanos observantes portugueses em tempos de Fr. João da Póvoa". Via Spiritus, 6: 227-231.

Carvalho, José Adriano de Freitas (2001) “As Crónicas da Ordem dos Frades Menores de fr. Marcos de Lisboa, ou a história de um triunfo anunciado". In Quando os frades faziam história. De Marcos de Lisboa a Simão de Vasconcelos, directed by Carvalho, José Adriano de Freitas. CIUHE, Porto: 9-81.

Cohen, Thomas M. (1998) The fire of tongues: António Vieira and the Missionary Church in Portugal and Brazil. Stanford University Press, Stanford.

Costa, Leonor Freire and Cunha, Mafalda Soares da (2008) D. João IV, 1604-1656. Temas \& Debates, Lisbon.

Cunha, J. Gerson da (ed.)(1877) The Sayhadrikhanda of the Skanda Purana. A Mythological, Historical, and Geographical Account of Western India. first Edition of the Sanskrit Text with Various Readings (Eighteenth-Century). Tacker, Vining and Co., Bombay.

Ferreira, José Miguel Moura (2011) A Restauração de 1640 e o Estado da Índia. Agentes, espaços e dinâmicas (MPhil thesis). Faculdade de Ciências Sociais e Humanas, Lisbon.

Finlay, Robert (1998) "Prophecy and Politics in Istanbul: Charles V, Sultan Süleyman, and the Habsburg Embassy of 1533-1534"'. Journal of Early Modern History, 2 (1): 1-31.

Fleischer, Cornell (2007) "Shadows of Shadows: Prophecy in Politics in 1530s Istanbul". International Journal of Turkish Studies, 13: 51-62.

Flores, Jorge and Silva, Nuno Vassallo e (eds.) (2004) Goa and the Great Mughal. Calouste Gulbenkian Foundation, Lisbon-London.

Frugoni, Francesca (1993) Francesco e l'invenzione delle stimmate: una storia per parole e immagine fino a Bonaventura e Giotto. G. Einaudi, Torino.

Ganeri, Jonardon (2011) The lost age of reason. Philosophy in Early-Modern India. Oxford University Press, Oxford.

García-Arenal, Mercedes (ed.) (2000) Mahdisme et millénarisme en Islam. special issue of Revue des mondes musulmans et de la Méditerranée: 91-94.

Gomes, Olivinho (ed.) (1996) Konkani Ramayana. Pre XVIth Century Ramayana in Konkani. Goa University, Goa (India)
Gomes, Olivinho (1999) Old Konkani language and literature: the Portuguese role. Konkani Sorospot Prakashan, Goa (India).

Haidar, Navina Najat and Sardar, Marika (2015) Sultans of Deccan India, 1500-1700, Opulence and Fantasy. Metropolitan Museum of Art, New York

Jordán, Maria V. (2003) "The Empire of the Future and the Chosen People: Father Antonio Vieira and the Prophetic tradition in the Hispanic World". Luso-Brazilian Review, 41: 46-57.

Kagan, Richard L. (1990) Lucrecia's Dreams: Politics and Prophecy in Sixteenth-century Spain. University of California Press, Oakland.

Kantor, Iris (2007) "Do dilúvio universal ao Pai Tomé: fundamentos teológico-políticos e mensuração do tempo na historiografia brasílica (1724-1759)". In Cultura Intelectual das Elites Coloniais, organized by Xavier, Ângela Barreto and Santos, Catarina Madeira. special issue of Cultura. Revista de História e Teoria das Ideias, 24: 181-193.

Koch, Ebba (2001) Mughal Art and Imperial Ideology: Collected Essays. Oxford University Press, New Delhi.

Koch, Ebba (2012) "The Symbolic Possession of the World: European Cartography in Mughal Allegory and History Painting". In Cultural Dialogue in South Asia and Beyond: Narratives, Images and Community [sixteenth-nineteenth centuries], edited by C. Lefèvre and I. G. Zupanov. special issue of JESHO, 55 (2-3): 547-580.

Lefèvre, Corinne (forthcoming) "Messianism, rationalism and inter-Asian connections: the Mughals and their theologians (c. 1610)". In From Timur to Nadir Shah: Connecting Iran, India and Central Asia, edited by Charles Melville. Brill, Leiden

Lerner, R. E. (1983) The Powers of Prophecy The Cedar of Lebanon vision from the Mongol Onslaught to the Enlightenment. Berkeley, University of California Press.

Lima, Luís Filipe Silvério (2010) O Império dos Sonhos: Narrativas proféticas, sebastianismo e messianismo brigantino. Alameda editora, São Paulo.

Marques, João Francisco (1988) A Parenética Portuguesa e a Restauração (1640-1668), 2 vols. INIC, Lisbon.

Marques, João Francisco (2007) A utopia do quinto império e os pregadores da Restauração. Quasi, Vila Nova de Famalicão.

Mello, Evaldo Cabral de (1997) O Rubro Veio. 2 (ed.). Topbooks, Rio de Janeiro.

Mendonça, Manuela (coord.) (2004) O Sebastianismo: politica, doutrina e mito (séculos XVI-XIX): Actas do colóquio da Academia Portuguesa da História. Colibri, Lisboa.

Michell, George (1995) Architecture and Art of Southern India. The New Cambridge History of India: Cambridge University Press, Cambridge

Michell, George and Zebrowski, Mark (1999) Architecture and Art of the Deccan Sultanates. The New Cambridge History of India: Cambridge University Press. Cambridge

Mitchell, W. J. T. (2005) What do Pictures Want? Lives and Love of Images. The University of Chicago Press, Chicago and London.

Moin, Azfar (2012) The Sacred Sovereign, Sacred Kingship and Sainthood in Islam. Columbia University Press, New York.

O'Hanlon, Rosalind and Christopher Minkowski (2008) "What Makes People Who They Are? Pandit Networks and the Problem of Livelihoods in Early Modern Western India”. The Indian Economic and Social History Review, 45 (3): 381-416.

Phelan, John Leddy (1970) The Millenial Kingdom of the Franciscans in the New World. University of California Press.

Pirbhai, M. Reza (2009) Reconsidering Islam in a South Asian context. Brill, Leiden-Boston.

Rosa, Maria de Lurdes (2010) Santos e Demónios no Portugal medieval. Fio da Palavra Editores, Lisbon.

Stuczinski, Claude B. (2008) "Providentialism in early modern catholic iberia: competing influences of Hebrew Political traditions". Hebraic Political Studies, 3 (4): 377-395.

Souza, Patricia Faria e (2013) A conquista das almas do oriente: Franciscanos, catolicismo e poder colonial português em Goa (1540-1740). 7 Letras, Rio de Janeiro.

Subrahmanyam, Sanjay (2001) "Du Tage au Gange au XVIe siècle: une conjoncture millénariste à l'échelle eurasiatique". Annales HSS, 56 (1): 51-84. 
Subrahmanyam, Sanjay (2012) Courtly Encounters. Translating Courtliness and Violence in Early Modern Eurasia. Harvard University Press. Cambridge, Mass./London.

Teles, João da Cunha (2011) "O inusitado no quotidiano de Goa: O mosteiro de Santa Mónica e o milagre da Cruz em 1636". Blogue de História Lusófona, Ano VI: Agosto http://www2.iict. $\mathrm{pt} /$ archive/doc/bHL Ano VI 14 Joao Teles e Cunha O inusitado_no_quotidiano_de_Goa._O_mosteiro_de_Santa Monica e o milagre da Cruz.pdf ${ }^{-}$[searched on $13 /$ Janu$\operatorname{ary} / 201 \overline{5}]$

Thomaz, Luís Filipe (1990) "L'idée imperiale manueline". In La découverte, le Portugal et l'Europe, edited by Jean Aubin. Centre Calouste Gulbenkian, Paris: 35-103.

Torgal, Luís Filipe Reis (1982) Ideologia Politica e Teoria do Estado na Restauração. 2 vols. Biblioteca Geral da Universidade de Coimbra, Coimbra

Trindade, Paulo da (1962) Conquista Espiritual do Oriente, vol. I. Centro de Estudos Históricos Ultramarinos, Lisboa.

Trindade, Paulo da (1964) Conquista Espiritual do Oriente, vol. II. Centro de Estudos Históricos Ultramarinos, Lisboa.

Valdez, Maria Ana T. (2010) Historical Interpretations of the "Fifth Empire": The Dynamics of Periodization from Daniel to António Vieira, S.J. Leiden: Brill.

Vieira, António, SJ (1718) História do futuro. Livro Anteprimeiro, Off. Antonio Pedrozo Galram, Lisbon.

Vieira, António, SJ (2007) (Seventeenth-Century) Esperanças de Portugal. Quinto Império do Mundo. Ática, Lisbon.

Vieira, António (2000) (Seventeenth-Century) Clavis Prophetarum, L. 3. Biblioteca Nacional, Lisbon.

Winius, George (2001) "Millenarism and Empire. Porutguese Asian decline and the 'Crise of Conscience' of the Missionaries". In Studies on Portuguese Asia, 1495-1689, edited by George D. Winius. Ashgate, Aldershot; Burlington, USA: 37-51.
Xavier, Ângela Barreto (1997) “'Nobres por geração'. A consciência de si dos descendentes de portugueses na Goa seiscentista". In Cultura Intelectual das Elites Coloniais, organized by Xavier, Angela Barreto and Santos, Catarina. Special issue of Cultura-História e Teoria das Ideias, 25: 89-118.

Xavier, Ângela Barreto (1998) A Invenção de Goa. Poder Imperial e Conversões Culturais nos séculos XVI e XVII. Imprensa de Ciências Sociais, Lisbon.

Xavier, Ângela Barreto (2014a) “"A maior empresa que nunca um príncipe cristão teve nas mãos'. Conquistar e conservar territórios no Índico nos tempos de Maquiavel". Tempo, 21: 1-27.

Xavier, Ângela Barreto (2014b) "Frei Miguel da Purificação entre Madrid e Roma. Relato de uma viagem à Europa de um frade português nascido na Índia”. In Clero, erudición y cultura escrita en los imperios ibéricos de la Edad Moderna, organized by Federico Palomo. Special issue of Cuadernos de Historia Moderna Anejos (La memoria del mundo), XIII: 87-110.

Xavier, Ângela Barreto and Cardim, Pedro (2006) Afonso VI. Círculo de Leitores, Lisboa.

Xavier, Ângela Barreto and Županov, Ines (2015) Catholic Orientalism. Portuguese empire, Indian knowledge, 16th-18th centuries. Oxford University Press, Delhi.

Zimmer, Heinrich (1997) Mitos e Símbolos na arte e civilização indianas. Lisboa, Assírio \& Alvim.

Županov, Ines G. (1999) Disputed Mission: Jesuit Experiments and Brahmanical Knowledge in Seventeenth-century. Oxford University Press, Delhi.

Županov, Ines (2007) “A 'Historia do Futuro'. Profecias móveis de jesuítas entre Nápoles, Índia e Brasil (século XVII)". In Cultura Intelectual das Elites Coloniais, organized by Xavier, Angela Barreto and Santos, Catarina Madeira. Special issue of Cultura, Revista de História e Teoria das Ideias, 25: 123-161. 